ISSN: 0213-2060

DOI: https://doi.org/10.14201/shhme20183615784

\title{
ENCUADRAMIENTO DEL CLERO LOCAL Y REORGANIZACIÓN ECLESIÁSTICA EN LA DIÓCESIS DE LEÓN (SIGLOS XI-XIII)
}

\author{
Local Clergy and Ecclesiastical Reorganization in the Diocese of Leon \\ (11 $1^{\text {th }}-13^{\text {th }}$ Centuries)
}

Mariel PÉREZ

Depto. de Historia. Facultad de Filosofia y Letras. Universidad de Buenos Aires. Puán, 480, piso 3..$^{\circ}$ of. 333. Ciudad Autónoma de Buenos Aires (Argentina) - Consejo de Investigaciones Cientificas y Técnicas (CONICET, Argentina).C.e.:perez_mariel@yahoo.com.ar

Recibido: 2017-02-07

Revisado: 2018-04-04

Aceptado: 2018-05-18

RESUMEN: El presente trabajo analiza las transformaciones experimentadas por el clero local en la diócesis de León entre mediados del siglo XI y principios del XIII a fin de comprender el proceso de encuadramiento de este grupo dentro de los nuevos marcos de organización eclesiástica impulsados por la Reforma Gregoriana. Con este fin, se examinan aspectos como los cambios en los mecanismos de acceso al clero, la subordinación de los clérigos locales a la jurisdicción episcopal, su adecuación a ciertas pautas de disciplina y comportamiento, y su participación en los ingresos eclesiásticos, en un contexto caracterizado por el fortalecimiento del poder episcopal y la configuración del sistema parroquial en el norte hispánico.

Palabras clave: Clero local; Poder episcopal; Reforma Gregoriana; Sistema parroquial; Diócesis de León.

ABSTRACT: This paper analyzes the transformations undergone by the local clergy in the diocese of Leon between the mid-eleventh and the beginning of the $13^{\text {th }}$ Century, with a view to shedding light on how this group adjusted to the new framework of ecclesiastical organization promoted by the Gregorian Reform. To this end, the study examines different 
aspects such as the changes in the ways clergymen were appointed, the subordination of local clergymen to the episcopal jurisdiction, their adjustment to certain standards of discipline and behavior, and their participation in the ecclesiastical income, within a context characterized by the strengthening of episcopal authority and the configuration of the parish system in northern Iberia.

Keywords: Local clergy; Episcopal authority; Gregorian Reform; Parish; Diocese of Leon.

SUMARIO: 0 Introducción. 1 Iglesias y clérigos locales en la Alta Edad Media. 2 El nombramiento del clero local. 3 Jurisdicción episcopal, disciplina y control del clero. 4 Los ingresos eclesiásticos y la tercia episcopal. 5 Conclusiones. 6 Referencias bibliográficas.

\section{INTRODUCCIÓN}

A mediados del siglo XI, a partir de la llamada Reforma Gregoriana, se puso en marcha en Europa occidental un profundo proceso de transformación de la institución eclesiástica orientado a renovar la vida y costumbres del clero, erradicar la injerencia de los laicos en los asuntos eclesiásticos y reorganizar el gobierno de la Iglesia bajo la autoridad centralizadora del Papado ${ }^{1}$. En este marco, se fortaleció el poder episcopal sobre las iglesias

1 Abreviaturas utilizadas: León III = Ruiz Asencio, José Manuel. Colección documental del Archivo de la Catedral de León (775-1230), vol. III (986-1031). León: Centro de Estudios e Investigación San Isidoro, 1990; León IV = Ruiz Asencio, José Manuel. Colección documental del Archivo de la Catedral de León (775-1230), vol. IV (1032-1109). León: Centro de Estudios e Investigación San Isidoro, 1990; León V = Fernández Catón, José María. Colección documental del Archivo de la Catedral de León (775-1230), vol. V (1109-1187). León: Centro de Estudios e Investigación San Isidoro, 1990; León VI = Fernández Catón, José María. Colección documental del Archivo de la Catedral de León (7751230), vol. VI (1188-1230). León: Centro de Estudios e Investigación San Isidoro, 1991; León VIII = Ruiz Asencio, José Manuel. Colección documental del Archivo de la Catedral de León (775-1230), vol. VIII (1230-1269). León: Centro de Estudios e Investigación San Isidoro, 1993; Sahagún I = Mínguez Fernández, José María. Colección diplomática del monasterio de Sahagún (siglos IX y X). León: Centro de Estudios e Investigación San Isidoro, 1976; Sahagún II = Herrero de LA Fuente, Marta. Colección diplomática del monasterio de Sahagún, vol. II (1000-1073). León: Centro de Estudios e Investigación San Isidoro, 1988; Sahagún III = Herrero de la Fuente, Marta. Colección diplomática del monasterio de Sahagún, vol. III (1073-1109). León: Centro de Estudios e Investigación San Isidoro, 1988; Sahagún IV = Fernández Flórez, José Antonio. Colección diplomática del monasterio de Sahagún, vol. IV (11101199). León: Centro de Estudios e Investigación San Isidoro, 1991; Sahagún V = Fernández Flórez, José Antonio. Colección diplomática del monasterio de Sahagún, vol. V (1200-1300). León: Centro de Estudios e Investigación San Isidoro, 1994.

Sobre los principales lineamientos de la Reforma Gregoriana, vid. Cowdrey, Herbert Edward John. Pope Gregory VII, 1073-1085. Oxford: Clarendon Press, 1998; Cushing, Kathleen G. Reform and papacy in the eleventh century: spirituality and social change. Manchester: Manchester University Press, 2005; FACI LACASTA, Francisco Javier. «Reforma gregoriana, reforma eclesiástica». En Ser Quijano, Gregorio del y MarTín VISO, Ińaki (eds.). Espacios de poder y formas sociales en la Edad Media: estudios dedicados a Ángel Barrios. Salamanca: Universidad de Salamanca, 2007, pp. 77-90; entre otros. 
ENCUADRAMIENTO DEL CLERO LOCAL Y REORGANIZACIÓN ECLESIÁSTICA EN LA DIÓCESIS DE LEÓN (SIGLOS XI-XIII) MARIEL PÉREZ

locales y comenzó a configurarse la parroquia "clásica», definida por la existencia de un templo parroquial, un párroco designado por el obispo encargado de administrar los sacramentos, una feligresía definida territorialmente y el pago obligatorio del diezmo ${ }^{2}$.

Las características que adquirieron estas transformaciones en los espacios que integraron el Reino de León han sido estudiadas desde diferentes perspectivas. En líneas generales, las investigaciones han prestado atención privilegiada a cuestiones como el papel desempenado por los diferentes agentes en la introducción de la Reforma Gregoriana en el ámbito hispánico -en particular, el Papado, la monarquía, los obispos y el clero cluniacense-, la acción de los obispos en la aplicación del programa reformista dentro de sus diócesis, los cambios en la organización eclesiástica y las relaciones que establecieron las iglesias hispanas con Roma ${ }^{3}$. Sin embargo, en las últimas décadas el programa de investigación se ha abierto a otras problemáticas. Debe destacarse, en este sentido, el interés que suscitó el estudio de la formación de las estructuras parroquiales desde la perspectiva de la organización social del espacio, que permitió iluminar el proceso que, entre los siglos XI y xIII, dio lugar a la configuración de una diócesis territorial y a la consolidación de la parroquia como referente fundamental de la ordenación espacial, social y religiosa de las sociedades del norte peninsular ${ }^{4}$. A su vez, ciertos aspectos del movimiento de reorganización eclesiástica abierto a

2 Sobre los aspectos generales de la institución parroquial y su desarrollo, vid. GaUdemet, Jean. «La paroisse au Moyen Âge». Revue d'Histoire de l'Église de France, 1973, vol. 59, n. ${ }^{\circ}$ 162, pp. 5-21; Aubrun, Michel. La paroisse en France des origines au XV siècle. Paris: Picard, 1986; entre otros.

3 Dentro de la amplia historiografía sobre la Reforma Gregoriana en el Reino de León pueden mencionarse, por su carácter general, FLETCHER, Richard. The Episcopate in the Kingdom of León in the Twelfth Century. Oxford: Oxford University Press, 1978; Rrvera Recio, Juan Francisco; FaCI Lacasta, Francisco Javier y Oliver, Antonio. «La presencia de la Santa Sede en España». En GarcíaVilloslada, Ricardo (dir.). Historia de la Iglesia en España. II. 1. La Iglesia en la España de los siglos VII al XIV. Madrid: Biblioteca de Autores Cristianos, 1982, pp. 259-297; ReILly, Bernard F. The Kingdom of Leon-Castilla under King Alfonso VI, 1065-1109. Princeton: Princeton University Press, 1988; Reglero DE LA Fuente, Carlos. "Los obispos y sus sedes en los reinos hispánicos occidentales». En La reforma gregoriana y su proyección en la cristiandad occidental: siglos XI-XII. XXXII Semana de Estudios Medievales. Estella, 18 a 22 de julio de 2005. Pamplona: Gobierno de Navarra-Institución Príncipe de Viana, 2006, pp. 195-288; Ayala Martínez, Carlos de. Sacerdocio y reino en la España altomedieval. Iglesia y poder politico en el Occidente peninsular, siglos VII-XII. Madrid: Sílex, 2008, pp. 295-415; CaLvo GómEZ, José Antonio. «Rasgos de la reforma del clero en la Península Ibérica durante el siglo XI». Studia Historica. Historia Medieval, 2015, vol. 33, pp. 201-232; entre otros.

4 Para los territorios del Reino de León las investigaciones se han centrado especialmente en las diócesis de Santiago de Compostela y Oviedo. Entre ellas se destacan los trabajos de López Alsina, Fernando. «Parroquias y diócesis: el obispado de Santiago de Compostela». En García de Cortázar, José Ángel (ed.). Del Cantábrico al Duero. Trece estudios sobre organización social del espacio en los siglos VIII a XIII. Santander: Universidad de Cantabria-Parlamento de Cantabria, 1999, pp. 263-312; ÍDEM. «El encuadramiento eclesiástico como espacio de poder: de la parroquia al obispado». En Iglesia Duarte, José Ignacio de la (coord.). Los espacios de poder en la España medieval. XII Semana de Estudios Medievales. Nájera, 30 de julio al 3 de agosto de 2001. Logroño: Instituto de Estudios Riojanos, 2002, pp. 425-457; ÍDEM. «La reforma eclesiástica: la generalización de un modelo parroquial renovado». En La reforma gregoriana y su proyección en la cristiandad occidental: siglos XI-XII. XXXII Semana de Estudios Medievales. Estella, 18 a 22 de julio de 2005. Pamplona: Gobierno de Navarra-Institución Príncipe de Viana, 2006, pp. 421-450; Calleja Puerta, Miguel. La formación 
mediados del siglo xI fueron estudiados en vinculación con otros fenómenos sociales, como las implicaciones que tuvo el avance episcopal sobre las iglesias propias en las relaciones entre la aristocracia laica y la Iglesia ${ }^{5}$, la incidencia del desarrollo de la red parroquial en la sujeción de las comunidades campesinas, la afirmación de la renta decimal y la consolidación del señorío episcopal ${ }^{6}$, el rol de la parroquia en la articulación social de las comunidades rurales ${ }^{7}$ o la dimensión religiosa que manifestó la lucha de clases a través de la resistencia campesina al pago del diezmo y a la intervención de los poderes eclesiásticos en las iglesias locales ${ }^{8}$.

En este marco historiográfico, el presente trabajo pone el foco de atención en el clero local -el grupo de clérigos a cargo de las iglesias de aldeas y villas- y se propone analizar, desde una perspectiva que jerarquiza los aspectos sociales, las transformaciones que experimentó este grupo a partir de la introducción de la Reforma Gregoriana en un contexto caracterizado por el fortalecimiento del poder episcopal y la formación de las estructuras parroquiales. Esto implica considerar con particular atención a aquellos clérigos vinculados a las iglesias propias, que con el avance de la reforma fueron quedando progresivamente subordinados a la jurisdicción episcopal y se vieron inmersos en un proceso de encuadramiento dentro de los nuevos marcos de organización eclesiástica. Se intentará, de este modo, atender a la necesidad de profundizar nuestros conocimientos sobre un sector social que, pese a su importancia en la articulación

de la red parroquial de la diócesis de Oviedo en la Edad Media. Oviedo: Real Instituto de Estudios Asturianos, 2000; ÍDEM. «Eclesiología episcopal y organización del espacio en las ciudades y villas del noroeste peninsular (1100-1250)». En Iglesia Duarte, José Ignacio (coord.). Monasterios, espacio y poder en la España cristiana medieval. XX Semana de Estudios Medievales. Nájera, 2009. Logroño: Instituto de Estudios Riojanos, 2010, pp. 429-490.

5 Martínez Sopena, Pascual. «Monasterios particulares, nobleza y reforma eclesiástica en León entre los siglos XI y XII». En Estudios de historia medieval. Homenaje a Luis Suárez Fernández. Valladolid: Universidad de Valladolid, 1991, pp. 323-331; ÍDEM. «Fundaciones monásticas y nobleza en los reinos de Castilla y León en la época románica». En García de Cortázar, José Ángel (coord.). Monasterios románicos y producción artística. Aguilar de Campoo: Fundación de Santa María la Real, 2003, pp. 3562; ÍDEM. "Aristocracia, monacato y reformas en los siglos XI y XII». En El monacato en los reinos de León y Castilla (siglos VII-XII). X Congreso de Estudios Medievales 2005. Ávila: Fundación Sánchez-Albornoz, 2007, pp. 67-100.

6 Martínez Sopena, Pascual. La Tierra de Campos occidental. Poblamiento, poder y comunidad del siglo X al XIII. Valladolid: Institución Cultural Simancas, 1985, pp. 273-304; Cimino, Carla. «Las iglesias locales, los señores feudales y la comunidad. Dinámicas de consolidación del episcopado castellano-leonés, 1150-1250». Trabajos y comunicaciones, 2013, vol. 39. En http://www.trabajosycomunicaciones.fahce.unlp.edu.ar/article/view/TyC2013n39a11.

7 Ruiz de la PeÑa, José Ignacio. «Parroquias, concejos parroquiales y solidaridades vecinales en la Asturias medieval». Asturiensia Medievalia, 1993-1994, vol. 7, pp. 105-122; ÍDEm. "La parroquia, célula de encuadramiento de la sociedad rural asturiana (siglos XI-XIII)». En SEsMa Muñoz, José Ángel y LaLiena Corbera, Carlos (coords.). La pervivencia del concepto: nuevas reflexiones sobre la ordenación social del espacio en la Edad Media. Zaragoza: Gobierno de Aragón y Grupo CEMA, 2008, pp. 197-218.

8 Alfonso Antón, Isabel. «Iglesias rurales en el norte de Castilla: una dimensión religiosa de las luchas campesinas en la Edad Media». En Robledo, Ricardo (ed.). Sombras del progreso. Las huellas de la historia agraria. Barcelona: Crítica, 2010, pp. 27-65. 
ENCUADRAMIENTO DEL CLERO LOCAL Y REORGANIZACIÓN ECLESIÁSTICA EN LA DIÓCESIS DE LEÓN (SIGLOS XI-XIII) MARIEL PÉREZ

social y religiosa de las sociedades medievales, no ha sido aún lo suficientemente estudiado para el período aquí abordado?.

El trabajo se centrará en la diócesis de León, en un arco temporal que se extiende desde mediados del siglo XI, con los primeros impulsos de renovación eclesiástica -aún pre-gregorianos- visibles en el concilio de Coyanza $(1055)^{10}$, a las primeras décadas del XIII, con el afianzamiento del sistema parroquial en la región, la institucionalización definitiva del cobro del diezmo y la introducción, a través del concilio de Valladolid de 1228, de las normas del IV Concilio de Letrán, punto aproximado de finalización del movimiento reformista iniciado en el siglo XI. La base documental de la investigación está constituida por las importantes colecciones diplomáticas de la catedral de León y el monasterio de Sahagún y las actas conciliares del Reino de León ${ }^{11}$. A este corpus se

9 En relación con el clero local, deben destacarse los aportes colectivos recogidos en BonnasSIE, Pierre (ed.). Le clergé rural dans l'Europe médiévale et moderne. Actes des XIII' Journées Internationales d'Histoire de l'Abbaye de Flaran, 6-8 septembre 1991. Toulouse: Presses Universitaires du Mirail, 1995; y Patzold, Steffen y Van Rhijn, Carine (eds.). Men in the Middle. Local Priests in Early Medieval Europe. Berlin: De Gruyter, 2016. Para el ámbito hispano, se destacan los estudios de José Luis Martín Martín, centrados en los siglos XIII a XV: «Beneficios y oficios del clero rural castellano (siglos XIII-Xv)». Anuario de Estudios Medievales, 2005, vol. 35, n. ${ }^{\circ} 2$, pp. 693-736; "El clero rural en la Corona de Castilla». En Martínez San Pedro, María de los Desamparados y Segura del Pino, Dolores (coords.). La iglesia en el mundo medieval y moderno. Almería: Instituto de Estudios Almerienses, 2004, pp. 55-82. Aborda las características del clero rural en el norte ibérico en el período pre-gregoriano, Davies, Wendy. «Local priests in northern Iberia». En Patzold y Van Rhijn, Men in the Middle, pp. 124-144. Debe mencionarse asimismo el reciente trabajo de José Antonio Calvo Gómez, que analiza la reforma del clero peninsular a mediados del siglo XI a partir de la introducción del programa gregoriano en la España cristiana, teniendo en cuenta el contexto político-eclesiástico europeo y las peculiaridades que impuso la «Reconquista» en la Península Ibérica, Calvo Gómez, «Rasgos de la reforma del clero».

10 Si bien es generalmente aceptado que el concilio de Coyanza se proponía llevar a cabo una restauración de la disciplina de la Iglesia leonesa en línea con la tradición hispano-visigótica (como sostuvo García Gallo, Alfonso. «El concilio de Coyanza. Contribución al estudio del Derecho Canónico español en la Alta Edad Media». Anuario de Historia del Derecho Español, 1951, vol. XIX-XX, pp. 275633), algunas de sus prescripciones -en particular, las referidas a las iglesias propias- confluían con los objetivos perseguidos por los reformadores gregorianos. Como ha señalado José Antonio Calvo Gómez, «esta regulación contribuyó de manera definitiva al fortalecimiento de la jerarquía episcopal y, en este sentido, resultó ampliamente coincidente con los postulados del papa Hildebrando y de los demás artífices de la Reforma Gregoriana», Calvo Gómez, «Rasgos de la reforma del clero», pp. 210-211. Lo mismo puede plantearse sobre los concilios de Compostela (1056 y 1063), que también habrían estado inspirados en la disciplina tradicional de la iglesia visigótica, como señala GARCía y García, Antonio. «Concilios y sínodos en el ordenamiento jurídico del reino de León». En Fernández Catón, José María (ed.). El Reino de León en la Alta Edad Media. 1. Cortes, concilios y fueros. León: Centro de Estudios e Investigación San Isidoro, 1988, p. 389.

11 Utilizamos la edición de Martínez DíEz, Gonzalo. Legislación conciliar del Reino Astur (718910) y del Reino de León (910-1230). León: Centro de Estudios e Investigación San Isidoro, 2009. Antonio García y García ha situado los concilios del Reino de León en tres etapas. La primera, pre-gregoriana, que incluye el Fuero de León de 1017 y los concilios de Coyanza (1055) y Compostela (1056). La segunda, plenamente gregoriana, que abarca toda la actividad conciliar entre 1081 (concilio de Burgos) y 1139 (fecha del II Concilio de Letrán, recibido por la legislación conciliar castellano-leonesa). Esta etapa 
añaden documentos pontificios relativos al ámbito hispano ${ }^{12}$, las constituciones de los sínodos diocesanos leoneses ${ }^{13}$ y el denominado Becerro de Presentaciones, que recoge datos sobre la organización eclesiástica de la diócesis leonesa a mediados del siglo XIII ${ }^{\mathrm{I}}$.

\section{Iglesias y Clérigos locales en la Alta Edad Media}

Wendy Davies ha definido a los clérigos locales como aquellos que no eran miembros de un monasterio establecido, de una catedral o de una casa real. Se trataría por tanto de clérigos del ámbito rural que, solos o junto a pequeñas comunidades, se hallaban a cargo de centros religiosos de irradiación local de heterogéneo carácter ${ }^{15}$. Comprender el proceso de encuadramiento de este grupo dentro de los emergentes marcos de organización diocesana nos obliga, pues, a delinear los rasgos que mostraban las iglesias locales y sus clérigos en la Alta Edad Media.

Desde el siglo Ix, en un marco signado por la desarticulación de las estructuras diocesanas heredadas del mundo visigodo y la debilidad de la autoridad episcopal, pero también por la expansión repobladora sobre los territorios situados entre la Cordillera Cantábrica y el Duero, tuvo lugar en la región el surgimiento de una multiplicidad de centros religiosos controlados por particulares (la familia real, la aristocracia laica, las comunidades campesinas, pequeñas comunidades monásticas e incluso los obispos y abades a título personal), que formaban parte del patrimonio de sus fundadores o sus descendientes y permanecían ajenos a la jurisdicción episcopal ${ }^{16}$. Estos establecimientos aparecen mencionados en las fuentes bastante indistintamente como iglesias o monasterios,

está caracterizada por la fuerte presencia de legados pontificios, que convocaron y presidieron numerosos concilios actuando como cauces de penetración de la reforma en el norte hispano. Finalmente, la tercera etapa abarca desde 1139 a 1230, fecha de unión definitiva de León y Castilla. García y García, Antonio. «Legislación de los concilios y sínodos del reino leonés». En Fernández Catón, José María (ed.). El Reino de León en la Alta Edad Media. 2. Ordenamiento jurídico del reino. León: Centro de Estudios e Investigación San Isidoro, 1992, pp. 9-113.

12 Mansilla Reoyo, Demetrio. La documentación pontificia hasta Inocencio III (956-1216). Roma: Instituto Español de Estudios Eclesiásticos, 1955; Domínguez SÁnchez, Santiago. Documentos pontificios referentes a la diócesis de León (siglos XI-XIII). León: Universidad de León, 2003.

13 García y García, Antonio. Synodicon Hispanum. Vol. 3: Astorga, León y Oviedo. Madrid: Biblioteca de Autores Cristianos, 1981.

${ }_{14}$ El Becerro de Presentaciones enumera los pueblos comprendidos dentro de la diócesis de León (clasificados por arcedianatos y arciprestazgos) e indica cuál era el santo titular de la iglesia local, quién tenía el derecho de presentación, a quién se entregaban las tercias y cuánto se pagaba en concepto de procuración. Ha sido editado por Fernández Flórez, José Antonio. «El Becerro de Presentaciones, códice 13 del Archivo de la Catedral de León. Un parroquial leonés de los siglos XIII-XV». En León y su historia. Miscelánea histórica, V. León: Centro de Estudios e Investigación San Isidoro, 1984, pp. 355-521.

15 DAviEs, «Local priests», pp. 127-128.

16 Para la organización eclesiástica del noroeste peninsular en el período anterior a la reforma eclesiástica remitimos a López Alsina, «La reforma eclesiástica», pp. 425-434, y Calleja Puerta, La formación de la red parroquial, pp. 39-64. 
ENCUADRAMIENTO DEL CLERO LOCAL Y REORGANIZACIÓN ECLESIÁSTICA

EN LA DIÓCESIS DE LEÓN (SIGLOS XI-XIII)

MARIEL PÉREZ

sin que se puedan apreciar diferencias nítidas entre ambas nociones. Esto ha llevado a M. ${ }^{a}$ Isabel Loring a plantear que se trataría de pequeñas iglesias servidas por grupos monásticos que, al mismo tiempo, ejercerían algunas funciones parroquiales ${ }^{17}$. Cabe señalar, en este sentido, que no fue sino hasta el Concilio de León de 1114 cuando se prohibió de forma expresa que los monjes ejercieran como parochiani presbyteri, inhabilitando la función parroquial de los monasterios y afirmando en consecuencia el rol de la parroquia como centro exclusivo de la cura de almas ${ }^{18}$.

Ahora bien, tras la categoría de iglesia propia se manifiesta una diversidad de situaciones concretas. Para la aristocracia, las iglesias propias -frecuentemente identificadas como monasterios y atendidas por un abad y una comunidad de fratres- funcionaban como centros de culto y lugares de enterramiento para los fundadores y sus descendientes. Esto no obsta para que además hayan podido desempeñar algunas funciones litúrgicas para la familia y las poblaciones locales ${ }^{19}$. Dentro de la sociedad campesina, los diplomas dan cuenta de una diversidad de situaciones: iglesias y monasterios vinculados a propietarios individuales, grupos de coherederos (herederos o diviseros) y comunidades campesinas, que podían estar a cargo de un abad o un presbítero -usualmente el fundador mismo de la iglesia o uno de sus herederos-, acompañado en ocasiones por una pequeña comunidad religiosa o hasta por su familia ${ }^{20}$. Los clérigos vinculados a estos centros religiosos eran generalmente personajes destacados en la sociedad campesina: tenían un estatus distinguido dentro de la aldea, actuaban como notarios -poniendo por escrito las transacciones de los habitantes de la villa o las de sus señores- y en muchos casos se encuentran documentados como propietarios múltiples a escala local, llegando a protagonizar procesos de acumulación de tierras a costa de otros campesinos ${ }^{21}$. Por otra

17 Loring García, María Isabel. «Nobleza e iglesias propias en la Cantabria altomedieval». Studia Historica. Historia Medieval, 1987, vol. V, pp. 90-93; señala también la confusión terminológica entre monasterium y ecclesia PeÑa Bocos, Esther. La atribución social del espacio en la Castilla altomedieval. Una nueva aproximación al feudalismo peninsular. Santander: Universidad de Cantabria, 1995, pp. 103 y ss.

18 Martínez Díez, Legislación conciliar, León (1114), 10.

19 Sobre las iglesias y monasterios de la aristocracia, vid. Loring García, «Nobleza e iglesias propias»; GARCÍA GARCÍA, Élida. «Monasterios benedictinos y aristocracia laica en Asturias (siglos XI y XII)». En Semana de Historia del Monacato Cántabro-Astur-Leonés. Oviedo: Monasterio de San Pelayo, 1982, pp. 195-233; Martínez Sopena, "Monasterios particulares»; ÍdEM, «Aristocracia, monacato y reformas»; Pérez, Mariel. «El control de lo sagrado como instrumento de poder: los monasterios particulares de la aristocracia altomedieval leonesa». Anuario de Estudios Medievales, 2012, vol. 42, n. ${ }^{\circ}$ 2, pp. 799-822.

20 Sobre esta variedad de situaciones, vid. Davies, Wendy. Acts of Giving: Individual, Community and Church in Tenth-Century Christian Spain. Oxford: Oxford University Press, 2007, pp. 46-48.

${ }^{21}$ El papel destacado de los presbíteros en las comunidades rurales ha sido ampliamente demostrado en la historiografía, vid. DAvies, Acts of Giving, pp. 46-49 y 97-106; DaviEs, «Local priests», pp. 137-139 y 142-143; Estepa Díez, Carlos. «Poder y propiedad feudales en el período astur: las mandaciones de los Flaínez en la montaña leonesa». En Miscel.lania en homenatge al P. Augusto Altisent. Tarragona: Diputació de Tarragona, 1991, pp. 309-310 y 326; Álvarez Borge, Ignacio. Poder y relaciones sociales en Castilla en la Edad Media. Los territorios entre el Arlanzón y el Duero en los siglos X al XIV. Salamanca: Junta de Castilla y León, 1996, p. 32; MarTín VIso, Ińaki. Poblamiento y estructuras 
parte, si bien es difícil saber hasta qué punto estos clérigos pudieron atender a las necesidades del culto en el ámbito local durante los siglos altomedievales, los libros litúrgicos que se enumeran en los documentos vinculados a las iglesias locales sugieren que muchos de ellos habrían estado en condiciones de celebrar los principales sacramentos y de participar en las oraciones comunitarias ${ }^{22}$.

Ya en el siglo x se advierte un movimiento de transferencia de iglesias y monasterios propios a las instituciones eclesiásticas, lo que se inscribía dentro del fenómeno más amplio de las donaciones por la salvación del alma. Los primeros beneficiarios de este movimiento fueron los grandes monasterios benedictinos, como el de Sahagún ${ }^{23}$. Pero fue en el siglo XI cuando la Iglesia leonesa empezó a mostrar su preocupación por el control de estas iglesias y sus clérigos. Esto se manifiesta de forma explícita en el concilio de Coyanza de 1055, que -aún dentro del marco doctrinal de la legislación visigoda- revela una voluntad de fortalecer la autoridad episcopal sobre las iglesias de la diócesis y de limitar la injerencia de los laicos sobre las mismas. El canon III establece, en efecto, que todas las iglesias que formen parte de una diócesis permanezcan bajo jurisdicción de sus obispos, que los clérigos no presten ningún servicio a los laicos y que las iglesias no sean divididas entre los presbíteros ${ }^{24}$. A su vez, tras la introducción de las nociones gregorianas en la Península, se profundizaron las medidas en esta dirección, prohibiéndose que los clérigos obtuvieran iglesias y beneficios de manu de los laicos y que estos detentaran bienes eclesiásticos o se apropiasen de diezmos y ofrendas ${ }^{25}$.

Ahora bien, los mecanismos a través de los cuales las iglesias propias se fueron subordinando al poder episcopal fueron dispares en la Península Ibérica ${ }^{26}$. En León, la documentación diplomática pone de manifiesto que el avance de los poderes eclesiásticos sobre las iglesias propias se llevó a cabo, al menos formalmente, a través de la donación de estos centros religiosos por parte de sus propietarios. Si en una primera etapa las donaciones tuvieron como principal beneficiario al monasterio de Sahagún, desde la segunda mitad del siglo XI estas se orientaron con creciente intensidad hacia la catedral de León, que adquirió un papel protagónico en la absorción de iglesias y monasterios

sociales en el norte de la Peninsula Ibérica (siglos VI-XIII). Salamanca: Universidad de Salamanca, 2000, pp. 192-194; MariÑo VeIras, Dolores. «Renovación cultural y monástica en León y Castilla al servicio del poder público-religioso: el protagonismo de presbíteros y diáconos durante el segundo tercio del siglo X». En Torres Prieto, Juana María (ed.). Historica et Philologica in honorem José María Robles. Cantabria: Universidad de Cantabria, 2002, pp. 153-168; Godoy, Analía. «Los presbíteros locales y sus estrategias de ascenso social en las comunidades campesinas leonesas del siglo X». Calamus, 2017, vol. 1, pp. 105-136.

${ }_{22}$ DAVIES, «Local priests», pp. 139-142.

23 Martínez Sopena, La Tierra de Campos, p. 293. Sobre las transacciones de iglesias propias en los siglos IX y x, véase también Davies, Acts of Giving, pp. 37-64.

24 MarTínez Díez, Legislación conciliar, Coyanza (1055), III.

25 Martínez Díez, Legislación conciliar, León (1114), III, VII; Burgos (1117), VIII, XI; Sahagún (1121), 10; Palencia (1129), 4, 10, 17.

26 Catalán Martínez, Elena. "Parroquias y curas en el obispado de Calahorra y La Calzada (siglos XI-XVI)». Obradoiro de Historia Moderna, 2013, vol. 22, pp. 39-40. 
ENCUADRAMIENTO DEL CLERO LOCAL Y REORGANIZACIÓN ECLESIÁSTICA

EN LA DIÓCESIS DE LEÓN (SIGLOS XI-XIII)

MARIEL PÉREZ

propios $^{27}$. Paralelamente, algunos propietarios pusieron a los clérigos de sus iglesias bajo jurisdicción episcopal y cedieron al obispo la tercera parte de los diezmos recaudados en las mismas ${ }^{28}$. Estos serían los primeros pasos de un proceso que condujo, entre los siglos XI y XIII, a la configuración de un nuevo modelo de organización eclesiástica que articulaba a las parroquias con el obispo, en el marco de una diócesis territorial. Este proceso no estaría exento de dificultades, ya que la imposición de la jurisdicción episcopal sobre las iglesias locales implicó en muchos casos realizar ciertas concesiones a los propietarios de iglesias o incluso enfrentar su resistencia abierta ${ }^{29}$.

Por otra parte, la sujeción de las iglesias y sus clérigos a la jurisdicción episcopal y su inserción dentro de las emergentes estructuras parroquiales involucró profundas transformaciones en el clero local, que debió someterse, como veremos, a las nuevas reglas de juego impuestas por las jerarquías eclesiásticas a partir de la Reforma Gregoriana.

\section{EL NOMBRAMiENTO DEL CLERO LOCAL}

Analizar la implantación del control episcopal sobre los clérigos locales implica dar cuenta de una multiplicidad de aspectos heterogéneamente reflejados en la documentación: los mecanismos de acceso al clero, su adecuación a ciertas pautas de disciplina, la regulación de la práctica litúrgico-pastoral o su participación en los ingresos eclesiásticos.

Un primer elemento para examinar es la forma en que estos clérigos llegaban a estar al frente de las iglesias locales, lo que nos lleva a considerar problemas como la ordenación, el nombramiento y el papel de los laicos en su elección. En la Alta Edad Media, como hemos visto, los centros religiosos que no se hallaban integrados dentro de complejos monásticos más amplios o subordinados a sedes diocesanas solían estar a cargo de clérigos nombrados por sus propietarios o de quienes -ordenados o no por el obispo-se colocaban a sí mismos al frente de las iglesias que controlaban en calidad de fundadores o herederos. Es difícil saber si estos clérigos habían recibido algún grado de ordenación. Las ordines de mediados del siglo XI, que recoge la tradición litúrgica visigoda, incluyen

27 El proceso de absorción de iglesias propias por parte de la catedral de León puede seguirse a través de los diplomas conservados en los fondos catedralicios: León III, doc. 548, 991; doc. 701, 1011; doc. 629, 1002; doc. 770, 1020; León IV, doc. 952, 1037; doc. 992, 1040; doc. 1002, 1042; doc. 1009, 1043; doc. 1047, 1047; doc. 1083, 1052; doc. 1115, 1059; doc. 1119, 1060; doc. 1143 , 1066; doc. 1163, 1069; doc. 1172, 1070; doc. 1197, 1076; doc. 1209, 1078; doc. 1248, 1090; doc. 1266, 1092; doc. 1267, 1092; doc. 1271, 1092; doc. 1276, 1093; doc. 1281, 1094; doc. 1316, 1104; doc. 1319, 1105; León V, doc. 1344, 1113; doc. 1366, 1120; doc. 1380, 1124; doc. 1437, 1142; doc. 1441, 1143; doc. 1500, 1157; doc. 1551, 1169; doc. 1581, 1174; doc. 1593, 1176; doc. 1594, 1176; doc. 1602, 1177; doc. 1603, 1177; doc. 1619, 1181 .

28 León IV, doc. 1136, 1065; doc. 1142, 1066; doc. 1175, 1071; doc. 1176, 1071.

29 Para el espacio leonés, abordan estos procesos Martínez Sopena, «Aristocracia, monacato y reformas»; PÉREZ, Mariel. «Proprietary Churches, Episcopal Authority and Social Relationships in the Diocese of León (11 $1^{\text {th }}-12^{\text {th }}$ Centuries)». Journal of Medieval Iberian Studies, 2018, vol. 10, n. ${ }^{\text {2 }}$, pp. 195-212. En https://www.tandfonline.com/doi/full/10.1080/17546559.2017.1315645. 
ENCUADRAMIENTO DEL CLERO LOCAL Y REORGANIZACIÓN ECLESIÁSTICA EN LA DIÓCESIS DE LEÓN (SIGLOS XI-XIII) MARIEL PÉREZ

el rito de ordenación de los presbíteros ${ }^{30}$. A su vez, la documentación diplomática ofrece algunas referencias aisladas a la ordenación de estos clérigos locales ${ }^{31}$. No obstante, Wendy Davies ha sugerido la posibilidad de ordenaciones no canónicas y de clérigos no ordenados, sobre todo en las regiones en las que la presencia de los obispos era aún débil ${ }^{32}$.

Los concilios de Compostela (1056 y 1063) ${ }^{33}$ establecieron una serie de prescripciones relativas a la ordenación del clero, que quedaba bajo responsabilidad de los abbates -figura que pronto fue reemplazada por la del arcediano- ${ }^{34}$, a cargo de la formación de los postulantes y de su presentación ante el obispo para su ordenación. Estos abbates, en virtud de su función, debían tener conocimientos de teología, de las Escrituras y de derecho canónico. A ellos les correspondía constatar que los postulantes a las órdenes (subdiáconos, diáconos y presbíteros) conocieran de memoria el salterio, con himnos y cánticos, y supieran llevar a cabo los ritos de bautismo y enterramiento, lo que iba delineando las funciones propias del clero parroquial. La edad mínima de ordenación se fijó en 18 ańos para los subdiáconos, 25 para los diáconos y 30 para los presbíteros ${ }^{35}$. A su vez, se estableció que solo quienes contaban con algún grado de ordenación clerical podrían acceder a un beneficio ${ }^{36}$.

Con el tiempo, los mecanismos de ingreso al clero y de acceso al beneficio eclesiástico fueron definiéndose con mayor detalle. José Luis Martín indica que en el siglo XIII el procedimiento más común consistía en que los arcedianos presentaran a los candidatos a órdenes ante la curia diocesana, donde clérigos de prestigio examinaban la idoneidad de los mismos y aprobaban su ordenación y nombramiento. No obstante, en las iglesias bajo régimen de patronato eran los patronos quienes presentaban a los clérigos para su designación. Por otra parte, se fueron estableciendo los requisitos que debían reunir los aspirantes, si bien eran muchas veces eludidos en la práctica. De especial importancia en un contexto feudal fue la condición jurídica: solo podían ser ordenados los hombres libres. La edad mínima para la ordenación solía fijarse en los 14 años, si bien algunos textos jurídicos como las Partidas consentían la concesión de beneficios desde los 7 años. Por otra parte, en algunas diócesis se exigía un beneficio como condición para aspirar a recibir las órdenes sagradas, lo que se vinculaba con la preocupación de las jerarquías eclesiásticas por las necesidades materiales del clero rural ${ }^{37}$. En cuanto a la formación, se

30 FÉRotin, Marius. Le Liber Ordinum en usage dans l'Église wisigothique et mozarabe d'Espagne du cinquième au onzième siècle. Paris: Librairie de Firmin Didot, 1904, cols. 54-55.

31 «Filio meo Placenti ad ordinacione presbiteri ante episcopus nomen acepi Salbator presbiter», Sahagún II, doc. 416, 1025.

32 DAvies, «Local Priests», pp. 131-132.

33 La celebración en Compostela de uno o más concilios durante el reinado de Fernando I y su posible datación han sido objeto de largo debate. Actualmente se postula la celebración de dos concilios, en 1056 y 1063, respectivamente; vid. Martínez Díez, Legislación conciliar, pp. 87-97. Por su parte, Fernando López Alsina data el primero de ellos en 1059, López Alsina, «El encuadramiento eclesiástico", p. 427, n. 5.

34 López Alsina, «El encuadramiento eclesiástico», p. 436.

35 Martínez Díez, Legislación conciliar, Compostela (1056), II-1, 2; Compostela (1063), II.

36 Ibidem, Compostela (1063), IV.

37 Sobre los mecanismos de acceso al clero y los requisitos de los aspirantes remitimos a MarTín Martín, «Beneficios y oficios», pp. 697-704. 
ENCUADRAMIENTO DEL CLERO LOCAL Y REORGANIZACIÓN ECLESIÁSTICA

EN LA DIÓCESIS DE LEÓN (SIGLOS XI-XIII)

MARIEL PÉREZ

exigía que los candidatos supieran leer, cantar y hablar latín, aunque no se establecía el nivel de esos conocimientos. En el siglo xiII, la formación de los clérigos pasaría a ser responsabilidad de los obispos, quienes debían instruir a los candidatos -por sí mismos o por medio de maestros- en los oficios divinos y la administración de los sacramentos. En este contexto, las nuevas escuelas diocesanas enfocaron su enseñanza en la gramática (entendida como vehículo de expresión de la teología) y el canto llano ${ }^{38}$.

La introducción de la Reforma Gregoriana en el norte hispánico implicó regular los mecanismos de provisión eclesial, combatiendo la simonía y la investidura laica ${ }^{39}$. Ya en el concilio de Compostela de 1056 se condenaban las prácticas simoníacas, lo que se reiteraría en concilios propiamente gregorianos de las primeras décadas del siglo $\mathrm{XII}^{40}$. A su vez, los concilios de León (1114), Burgos (1117), Sahagún (1121) y Palencia (1129) condenaron enfáticamente la intervención de los laicos y los poderes seculares en la provisión de iglesias y beneficios ${ }^{41}$. De todos modos, el cumplimiento de esta normativa tuvo sus limitaciones. Las constituciones sinodales de fines del siglo XIII insistían en que los clérigos no debían recibir beneficios de manos de patronos laicos o eclesiásticos sin aprobación del obispo, lo que evidencia la larga supervivencia de esta práctica. Se condenaba, asimismo, a los clérigos que pagaban a los patronos para obtener la presentación con la pérdida del oficio y el beneficio ${ }^{42}$.

Ahora bien, si el avance episcopal sobre las iglesias propias suponía la supresión del nombramiento laico y la regulación de los mecanismos de acceso a las órdenes y beneficios, esto no implicó necesariamente que aquellos que habían tenido derechos de propiedad sobre iglesias locales hubieran perdido toda capacidad de injerencia en la elección

38 Sото Rábanos, José María. «Pedagogía medieval hispana: transmisión de saberes en el bajo clero». Revista Española de Filosofia Medieval, 1995, vol. 2, pp. 50-51.

39 Como señala Francisco Javier Faci Lacasta, «los problemas que planteaban las Iglesias peninsulares eran semejantes a las del resto de Europa, y, por lo tanto, también las soluciones se asemejaban. [...] España no quedaba, ni mucho menos, fuera de los planes hegemónicos del pontificado, sino que ocupaba en ellos un papel muy importante. La reorganización eclesiástica que experimenta la cristiandad como consecuencia de la reforma gregoriana también tiene efectos en España», en FACi LACASTA y Oliver, «La presencia de la Santa Sede», p. 275. En la misma línea, Calvo Gómez, «Rasgos de la reforma del clero».

40 Martínez Díez, Legislación conciliar, Compostela (1056), II-3; León (1114), VII; Sahagún (1121), 10; Valladolid (1143), 1, 2. Fuera del Reino de León se destacan, en este sentido, los concilios de Gerona de 1068 y 1078, vid. Calvo Gómez, «Rasgos de la reforma del clero», pp. 220-225.

41 "Que ningún ordenado reciba la iglesia de mano laical» y «que ninguno venda una iglesia ni la compre, ni la escriture a favor de un laico, porque esto sería simoníaco», MarTínez DíEz, Legislación conciliar, León (1114), III, VII; «si algún obispo o clérigo de cualquier grado consiguiere una iglesia o un beneficio eclesiástico por medio de los poderes seculares, sea privado del oficio y beneficio eclesiástico», Burgos (1117), VIII; «que a aquellos que han sido elegidos o investidos por ambición, ruegos o precio o únicamente por laicos y todos los simoníacos, que nadie movido de misericordia los mantenga en su rango», Sahagún (1121), 10; "que los clérigos no acepten ni reciban iglesias de manos de los seglares ni los vicarios de los obispos lo toleren», Palencia (1129), 10; «si alguno acepta de mano laical cargos, prebendas y otros beneficios eclesiásticos, las cuales cosas nadie debe reclamar para sí alegando derecho perpetuo ni solicitar indignamente, pierda el beneficio recibido», Valladolid (1143), 18.

42 García y García, Synodicon Hispanum, León (1267-1262), 6; León (1288), 9. 
de los clérigos a cargo de las mismas tras subordinarlas a la sede catedralicia. De hecho, a partir de la Reforma Gregoriana comenzó a configurarse a través de las prácticas sociales concretas lo que a fines del siglo XII cristalizó en el derecho de patronato, que confería a propietarios laicos, comunidades rurales y monasterios la capacidad de presentar para la aprobación del obispo a los clérigos que habrían de servir sus iglesias ${ }^{43}$. La extensión que había alcanzado el patronato en la diócesis de León a mediados del siglo XIII se vio reflejada en el Becerro de Presentaciones, que revela la importante presencia de iglesias vinculadas a laicos (herederos, fijosdalgo, monarcas, concejos) y a instituciones religiosas que disfrutaban del derecho de presentación y de una participación en los diezmos y otros ingresos eclesiásticos ${ }^{44}$. Pero este sería el punto de llegada de una larga evolución marcada por la resistencia de los propietarios de iglesias, tanto laicos como eclesiásticos, y la necesidad del poder episcopal de concertar acuerdos negociados con los mismos.

Es conocida la larga disputa que, desde finales del siglo XI, enfrentó a los obispos de León con el monasterio de Sahagún por las iglesias del coto monástico y las que detentaba el monasterio dentro de la diócesis leonesa, disputa a lo largo de la cual se terminó afirmando el derecho de Sahagún a presentar a los clérigos de estas iglesias para su nombramiento $^{45}$. A su vez, la colegiata de San Isidoro de León -que en 1144 se estableció como comunidad de canónigos regulares- logró ejercer funciones parroquiales dentro de la ciudad de León ${ }^{46}$. Aquí fueron los propios canónigos quienes ejercían como clérigos, recibiendo la cura animarum del obispo ${ }^{47}$. Debe señalarse, en este sentido, el papel desempeńado por el Papado, que, si bien confirmó los privilegios de ciertas instituciones religiosas de la diócesis, limitó las prerrogativas de estas sobre sus iglesias y afirmó la

43 Desde un punto de vista jurídico, los rasgos del derecho de patronato fueron definidos en el III Concilio de Letrán (1179), 17. En el ámbito hispánico, la figura del patronato fue recogida en el concilio de Valladolid, (1228), XI. A su vez, se plasmó en la legislación civil en la Primera Partida, tít. XV, ley 1. Sobre la evolución del derecho de patronato en la Iglesia hispana, CaTALÁn MARTínez, Elena. «El derecho de patronato y el régimen beneficial de la Iglesia española en la Edad Moderna». Hispania Sacra, 2004, vol. 56, n. ${ }^{\circ} 113$, pp. 135-167; Díaz de Durana, José Ramón. «Patronatos, patronos, clérigos y parroquianos: los derechos de patronazgo sobre monasterios e iglesias como fuente de renta e instrumento de control y dominación de los parientes mayores guipuzcoanos (siglos XIV a XVI)». Hispania Sacra, 1998, vol. 50, n. ${ }^{\circ}$ 102, pp. 467-508. Otro mecanismo que en la Baja Edad Media permitió la injerencia de los laicos en las iglesias y el disfrute de sus bienes fue el de las iglesias patrimoniales, que no deben confundirse con las iglesias propias. Sobre el tema, se destaca el trabajo de Peñalva GiL, Jesús. "Las iglesias patrimoniales en la Castilla medieval. La iglesia parroquial de San Nicolás de Burgos: institución, ordenanzas y regla de 1408». Anuario de Estudios Medievales, 2008, vol. 38, n.o 1, pp. 301-366.

44 Fernández Flórez, «El Becerro de Presentaciones».

45 Algunos episodios que jalonan este conflicto son recogidos en León IV, doc. 1260, 1091; León V, doc. 1606, 1177; doc. 1648, [1184]; doc. 1663, [1186-1187]; León VI, doc. 1880, 1219; doc. 1849, [1215]; Sahagún V, doc. 1620, 1219; doc. 1777, 1260. Un estudio detallado de la disputa entre el monasterio y la sede leonesa en Álvarez Palenzuela, Vicente Ángel. «Jurisdicción episcopal y monástica: su delimitación entre el Obispado de León y el Monasterio de Sahagún». En Escritos dedicados a José María Fernández Catón. Vol. 1. León: Centro de Estudios e Investigación San Isidoro, 2004, pp. 65-85.

46 Calleja Puerta, «Eclesiología episcopal», pp. 475-476.

47 León V, doc. 1510, 1159. 
ENCUADRAMIENTO DEL CLERO LOCAL Y REORGANIZACIÓN ECLESIÁSTICA EN LA DIÓCESIS DE LEÓN (SIGLOS XI-XIII) MARIEL PÉREZ

subordinación jurisdiccional de las mismas a la sede episcopal, lo que se expresó, especialmente, en la obligación de recurrir al obispo para la consagración del óleo y el crisma, la ordenación de los clérigos y la consagración de basílicas y altares ${ }^{48}$.

En el caso de las iglesias que se hallaban bajo control laico, muchos de los antiguos propietarios lograron mantener su injerencia en la elección de los clérigos, si bien su nombramiento quedaba a cargo del obispo. El Becerro de Presentaciones incluye referencias a laicos de diversa condición que en el siglo xiII gozaban del derecho de presentación. Sin embargo, la documentación diplomática es más oscura en este sentido, ya que suele traslucir este fenómeno en el momento en que los laicos ceden los derechos sobre sus iglesias a las instituciones eclesiásticas. Así, cuando en 1214 el caballero don Rodrigo Pérez donó a la catedral de León las iglesias de San Pedro y San Félix de Villalobos, el obispo y el cabildo procedieron a confirmar a los clérigos que tenían dichas iglesias de manu domni Roderici Petri ${ }^{49}$.

Cuando las iglesias se hallaban controladas colectivamente por las comunidades rurales, el nombramiento de los clérigos podía estar mediado por el acuerdo del concejo. En 1102, el conde Martín Flaínez donaba a los hombres de Terradillos una tierra para que construyeran allí una iglesia; se establecía que el clérigo fuera nombrado por los hombres del concejo con acuerdo del obispo de León y del arcediano ${ }^{50}$. El derecho a la elección del clérigo local podía ser asimismo objeto de disputa, como muestra el conflicto entre el obispo don Manrique y el concejo de Rebollar. Los hombres del concejo afirmaban que la iglesia de la villa les pertenecía por derecho hereditario y que en ella no debía instituirse capellán sin aprobación del concejo. El arcediano negaba estas reivindicaciones, afirmando que la iglesia debía estar sujeta a la jurisdicción de la sede de León. Finalmente, los habitantes de la villa reconocieron que la iglesia y sus bienes se hallaban bajo autoridad de la sede y que no pertenecía a ningún heredero; en tales condiciones, no contaban con fundamentos para reivindicar su derecho a la elección del clérigo ${ }^{51}$.

Las comunidades también podían pactar con el obispo la posibilidad de que sus propios miembros tuvieran preferencia sobre otros individuos para ser nombrados clérigos en la iglesia local, prefigurando lo que tiempo más tarde -y bajo otras premisas- será conocido bajo el nombre de "clérigos patrimoniales" ${ }^{52}$. En 1172, el concejo de Tapioles donaba su iglesia a la sede de León para que el obispo la consagrase y nombrase un capellán qui sit bonus, et pacificus, et uiuat honeste. Se establecía, sin embargo, que, si un miembro de la comunidad fuera ordenado sacerdote, guardara obediencia a la sede leonesa y se comprometiera a vivir rectamente, este fuera preferido para ser nombrado clérigo de la iglesia frente a otros candidatos ${ }^{53}$. La iglesia se integraba, pues, al nuevo cuadro parroquial que

48 Vid. Domínguez SÁnchez, Documentos pontificios, docs. 13, 20, 26, 43, 47, 65 y 66, entre otros.

49 León VI, doc. 1838, 1214.

50 León IV, doc. 1313, 1102.

51 «Firmiter nitebantur affere omnes homines qui erant in predicta uilla quod ecclesia ipsa ad eos tamquam ad heredes iure hereditario pertinebat, et ideo sine consilio et eorum assensu, in ea non debebat institui capellanus», León V, doc. 1623, 1181.

52 Sobre los clérigos patrimoniales en la Baja Edad Media castellana, Martín Martín, «Beneficios y oficios», p. 702, y, con mayor profundidad, Peñalva GIL, «Las iglesias patrimoniales».

53 León V, doc. 1575, 1172. 
comenzaba a configurarse, pero a su vez el concejo lograba asegurar que siguiera estando a cargo de un miembro de la comunidad. En la misma dirección, pero esta vez mediante la intervención regia, Alfonso IX reconocía a la sede de León el pleno derecho sobre las iglesias de Riaño y Burón y ordenaba a Martín Alonso, arcediano de aquellas tierras, que repartiese los beneficios de aquellas iglesias entre los clérigos de dichas villas et non inter alios qui foras habitauerint ${ }^{54}$.

En algunos casos, la sede diocesana intentó librarse de la influencia de los concejos en la elección de los clérigos, apoderándose de todos los derechos de propiedad sobre la iglesia y eliminando así el patronato ejercido por la comunidad. Ilustra este fenómeno el conflicto que en 1182 enfrentó al obispo Manrique de León con los hombres y clérigos de la iglesia de Mansilla de las Mulas por la propiedad de la iglesia de la villa. Reunidas ambas partes en la corte regia, el obispo proponía que los clérigos que estaban a cargo de la iglesia de Santa María de Mansilla dimitieran, y que el concejo y los clérigos entregaran la iglesia a la sede de León para que esta la tuviera a perpetuidad por derecho hereditario. En compensación, permitía al concejo y a los clérigos quedar a cargo de cinco nuevas iglesias a construirse en la villa. Sin embargo, los clérigos de Mansilla se negaron a renunciar a sus cargos, por lo que el obispo y el concejo llegaron a un acuerdo: el obispo permitiría a los clérigos tener la mitad de dicha iglesia durante sus vidas en calidad de vasallos, pero, cuando alguno de ellos falleciere, su parte revertiría al obispo. Por tanto, una vez fallecidos todos los clérigos, la totalidad de la iglesia quedaría finalmente en poder de la sede de León ${ }^{55}$. La absorción de los derechos de propiedad sobre la iglesia de la villa permitiría a la sede leonesa nombrar clérigos bajo su control directo y sin lazos preexistentes con la comunidad, suprimiendo de este modo cualquier injerencia del concejo sobre la misma. Esto sería resultado de un proceso gradual, ya que, al no lograr que los clérigos dimitieran, el obispo debió aceptar que estos permanecieran en sus cargos de por vida, apropiándose progresivamente de sus derechos a medida que estos fueran falleciendo. Un acuerdo similar se pactó con los clérigos de la iglesia de Santiago de Malillos en 1232. En este caso se estableció que, cuando fallecieran los clérigos locales, sus derechos se fueran transfiriendo a quien tuviera la iglesia de parte de la sede de León y que, a la muerte de todos ellos, la sede finalmente quedara en libertad para disponer de la iglesia y nombrar clérigos sin mediación de los miembros de la vill ${ }^{56}$.

\section{JURISDICCIÓN EPISCOPAL, DISCIPLINA Y CONTROL DEL CLERO}

Desde mediados del siglo xi los documentos comienzan a introducir la noción de una jurisdicción episcopal a la que debían someterse todos los clérigos de la diócesis, en consonancia con el fortalecimiento de la autoridad episcopal que impulsaba la Reforma Gregoriana. Así, en 1065 el obispo Pelayo lograba que destacados miembros de la aristocracia leonesa pusieran a los clérigos de sus iglesias bajo su jurisdicción, comprometiéndose a no sacarlos de uestro iuditio, que fueran concurrentes et deseruientes a la

54 León VI, doc. 1887, [1219-1224].

55 León $\mathrm{V}$, doc. $1638,1182$.

56 León VIII, doc. 1992, 1232. 
ENCUADRAMIENTO DEL CLERO LOCAL Y REORGANIZACIÓN ECLESIÁSTICA

EN LA DIÓCESIS DE LEÓN (SIGLOS XI-XIII)

MARIEL PÉREZ

sede leonesa y que no apelasen a otra justicia nisi ad suo episcopo ${ }^{57}$. Los documentos que recogen la transferencia de iglesias propias a la sede diocesana expresan a su vez la idea de que los clérigos de las iglesias y monasterios locales debían prestar fidelidad y obediencia al obispo, lo que era particularmente enfatizado en los casos en los que estas quedaban vinculadas de alguna manera a sus antiguos propietarios. En 1104, Xabe Vélaz donaba a la sede de León el monasterio de San Salvador de Villabaruz, a condición de que su hijo Juan la tuviera mientras viva y que, a su muerte, la iglesia quedara a cargo de alguno de sus descendientes que fuese clérigo tamen fidelis et in omnibus obediens episcopo Sancte Maria existat ${ }^{58}$. Y en 1172, el concejo de Tapioles donaba su iglesia a la sede de León, estableciendo que, si algún miembro de la comunidad fuera ordenado sacerdote, tuviera prioridad para ser designado capellán de dicha iglesia, siempre y cuando quisiera vivir rectamente y sede Sancte Marie Legionensis ecclesie obediens fuerit ${ }^{9}$.

La subordinación a la autoridad episcopal suponía una adecuación de las prácticas del clero local a una serie de normas que regulaban los diversos aspectos de la actividad pastoral del clero y de su vida cotidiana. Ya en el concilio de Coyanza de 1055, que pretendía restaurar la disciplina eclesiástica apelando a la tradición hispanogótica, se establecía que los clérigos debían permanecer bajo jurisdicción del obispo, no prestar ningún servicio a los laicos y no dividir las iglesias; los que no obedecieran a los decretos pagarían una multa de 60 sueldos y perderían su grado eclesiástico. A su vez, el concilio recogía especificaciones sobre la dotación de las iglesias (ministros, libros litúrgicos, ornamentos), vestimenta de los clérigos y normas relativas a la práctica de los sacramentos ${ }^{60}$.

Las preocupaciones visibles en Coyanza confluyeron poco después con el programa de renovación del clero impulsado por el Papado. Así, los concilios hispanos condenaron los actos considerados simoníacos, como la compra de dignidades ${ }^{61}$, el nombramiento laico ${ }^{62}$ y la apropiación y enajenación de objetos eclesiásticos ${ }^{63}$. También se combatió el nicolaísmo, prohibiéndose la cohabitación con mujeres dentro de las iglesias ${ }^{64}$ así como el matrimonio y el concubinato del clero, que desde el siglo xir fue penado con la pérdida del oficio y el beneficio eclesiástico ${ }^{65}$. A su vez, el concilio de Palencia ordenaba que las concubinas de los clérigos fueran expulsadas de las iglesias ${ }^{66}$.

57 «Et non tollamus monacos de nostras ecclesias de uestro iuditio, set stent pro uestra parte et post partem uestri successores omnibus diebus», León IV, doc. 1136, 1065; «et stent illas ecclesias uel monasteri[os] uel monacos qui ibidem fuerint concurrentes et deseruientes ad sedis Legionense et non proclament se nisi ad suo episcopo et reddant suas tertias uel usuras tam in nostra uita quam in omni tempore», León IV, doc. 1142, 1066.

58 León IV, doc. 1316, 1104.

59 León V, doc. 1575, 1172.

60 Martínez Díez, Legislación conciliar, Coyanza (1055), III-V.

61 Ibidem, Compostela (1056), II, 3; Valladolid (1143), 1, 17.

${ }^{62}$ Ibidem, Burgos (1117), VIII; Valladolid (1143), 18.

63 Ibidem, Burgos (1117), V, XI, XVI.

64 Ibidem, Coyanza (1055), 3; Compostela (1056), III, 2; Compostela (1063), III; León (1114), 8.

65 Ibidem, Compostela (1056), IV, 1-2; Burgos (1117), II; Palencia (1129), 5; Valladolid (1143), 6-9.

${ }_{66}$ Ibidem, Palencia (1129), 5. 
Un problema específico que tuvieron que afrontar los reformadores gregorianos en el ámbito ibérico, en línea con la política unificadora que promovía el pontificado, fue la supresión de la liturgia hispana o mozárabe y su sustitución por el rito romano, lo que implicaba una unión de fe de las iglesias cristianas con la Iglesia romana y una sumisión plena de la Iglesia hispana al Papado. Ya Alejandro II (1061-1073) había reprobado la liturgia hispana, encomendando al cardenal Hugo Cándido renovar los confusos ritus que se practicaban en la península de acuerdo con el orden canónico. Pero fue Gregorio VII (1073-1085) quien emprendió una campaña sistemática contra la liturgia mozárabe. En 1074, en una carta dirigida a los reyes de Castilla y Navarra, el pontífice subrayaba el deterioro de la cristiandad hispana y exhortaba a las iglesias ibéricas a que recibiesen Romane ecclesie ordinem et officium ... non Toletane vel cuiuslibet alie ${ }^{67}$. Si bien el cambio de rito fue en principio resistido en el reino leonés, el concilio de Burgos de 1080 logró imponer la unificación litúrgica bajo los cánones romanos, obligando a las iglesias hispanas a abandonar el rito mozárabe ${ }^{68}$. El cambio de rito implicaría un largo proceso de aprendizaje y asimilación por parte del clero local, proceso que no estaría exento de dificultades y resistencias ${ }^{69}$. De hecho, la propia catedral de León se presentó, al menos en un primer momento, como uno de los focos de resistencia a la imposición del rito romano $^{70}$. En cualquier caso, la unificación litúrgica constituyó un aspecto fundamental en el encuadramiento del clero local dentro del nuevo modelo de organización eclesiástica promovido desde el Papado.

Las constituciones de los sínodos diocesanos, si bien más tardías, ofrecen un reflejo de las normas que pretendía imponer el obispo dentro de su diócesis, así como de los comportamientos y abusos en los que incurrían los clérigos ${ }^{71}$. Así, se insiste en la vestimenta y

67 Mansilla, La documentación pontificia, doc 4; doc. 8. Sobre el papel del cambio de rito dentro del programa reformista que el Papado pretendía imponer en el ámbito hispano, Soto RÁBANos, José María. «Introducción del rito romano en los reinos de España. Argumentos del papa Gregorio VII». Studi Gregoriani, 1991, vol. 14, pp. 161-174; Reglero de la Fuente, Carlos. "La Reforma Gregoriana y la introducción del rito romano». En Escudero, José Antonio (dir.). La Iglesia en la Historia de España. Madrid: Marcial Pons, 2014, pp. 317-326.

68 La sanción del cambio de rito, oficializada en el concilio de Burgos, se menciona en un diploma regio de mayo de 1080, Sahagún III, doc. 781, 1080. Sobre la fecha del concilio de Burgos, Reglero de la Fuente, Carlos. «La primera reforma cluniacense de Sahagún, el concilio de Burgos y la crisis de 1080: revisión cronológica y desarrollo». En Fernández Catón, José María (ed.). Monarquía y sociedad en el reino de León. De Alfonso III a Alfonso VII, vol. 2. León: Centro de Estudios e Investigación San Isidoro, 2007, pp. 689-732.

69 Aborda las dificultades que entrañó la implantación real del nuevo rito, tanto para los clérigos como para los fieles, Rubio Sadia, Juan Pablo. "La introducción del canto gregoriano en Aragón: etapas y vicisitudes de un proceso de asimilación (siglos IX-XII)». En Prensa, Luis y Calahorra, Pedro (coords.). Jornadas de Canto Gregoriano: XV. El libro litúrgico: del scriptorium a la imprenta. XVI. La implantación en Aragón, en el siglo XII, del rito romano y del canto gregoriano. Zaragoza: Institución Fernando el Católico, 2012, pp. 171-201.

70 Deswarte, Thomas. Une Chrétienté romaine sans pape: l'Espagne et Rome (586-1085). Paris: Garnier, 2010, pp. 410-414 y 418-480.

71 Las primeras constituciones sinodales leonesas conservadas datan de 1267 o 1272, GARCíA Y García, Synodicon Hispanum, pp. 232-233. 
ENCUADRAMIENTO DEL CLERO LOCAL Y REORGANIZACIÓN ECLESIÁSTICA

EN LA DIÓCESIS DE LEÓN (SIGLOS XI-XIII)

MARIEL PÉREZ

aspecto personal del clero, el correcto cumplimiento de los oficios y la actividad pastoral, y la adecuación a una serie de pautas de conducta compatibles con la dignidad clerical. Debe señalarse, en este sentido, el énfasis puesto por los obispos en limitar los vínculos entre los clérigos y la sociedad local, prohibiendo su participación dentro de los espacios de sociabilidad de las comunidades (ir a la taberna, embriagarse, jugar a los dados) así como su desempeño -bajo pena de la pérdida del beneficio- en actividades vinculadas a los poderes laicos, bien como merinos o mayordomos, bien como vasallos ${ }^{72}$. Esto resulta de gran interés, en tanto muestra los límites que presentó la conformación de un estamento clerical de perfiles nítidos y desvinculado de la sociedad laica.

La documentación diplomática no arroja demasiada luz sobre la disciplina del clero. Entre los datos aislados que nos acercan a los comportamientos del clero local en la diócesis de León, los diplomas permiten entrever la presencia de presbíteros con concubinas. En 1089, el presbítero Esteban aparecía junto a Gontrodo, calificada como mea seruiente, realizando una profiliación a sus criados Sidro y Sancho. Dado que ambos parecen tener bienes en común, haciendo referencia a omnia nostra eredidade, podría inferirse que Gontrodo era su concubina ${ }^{73}$. Esta situación no debía ser excepcional, si se considera que en 1245 Inocencio IV permitió al obispo de León levantar la excomunión, impuesta por el legado pontificio, a aquellos clérigos de su diócesis que tenían concubinas ${ }^{74}$. La documentación provee asimismo algunas referencias sobre clérigos con hijos. En 1080, el presbítero Abito hacía una donación al monasterio de Sahagún y establecía que los bienes donados quedaran en posesión de su hijo Facundo, quien debía servir con ellos al monasterio $^{75}$. Y en torno al 1124, el presbítero Peláez donaba junto con su hermana su iglesia en villa Bonellos a la sede de León, señalando que se reservaba el usufructo de la iglesia mientras vivieran ellos y sus respectivos hijos ${ }^{76}$. A su vez, en 1203 el monasterio de Sahagún concedía la mitad de la iglesia de San Miguel de Villárdiga al presbítero Martín y a su hijo Juan Martín ${ }^{77}$. Ciertamente, los presbíteros referenciados pudieron haber ingresado al sacerdocio habiendo tenido hijos con anterioridad. Por otro lado, el concilio de Valladolid (1143) establecía que «los hijos de los presbíteros sean removidos de los sagrados ministerios del altar, a no ser que hayan vivido religiosamente en los cenobios o en las casas canonicales" ${ }^{78}$, lo que evidencia que algunos clérigos no solo tenían hijos sino que estos solían suceder a sus padres en el oficio.

Debe considerarse asimismo la introducción de las visitas pastorales y los sínodos diocesanos como mecanismos de control episcopal y disciplinamiento del clero local. Miguel Calleja ha señalado que en el noroeste peninsular las visitas pastorales serían una práctica extendida para el siglo $\mathrm{XIII}^{79}$. La documentación de ese siglo ofrece, en efecto,

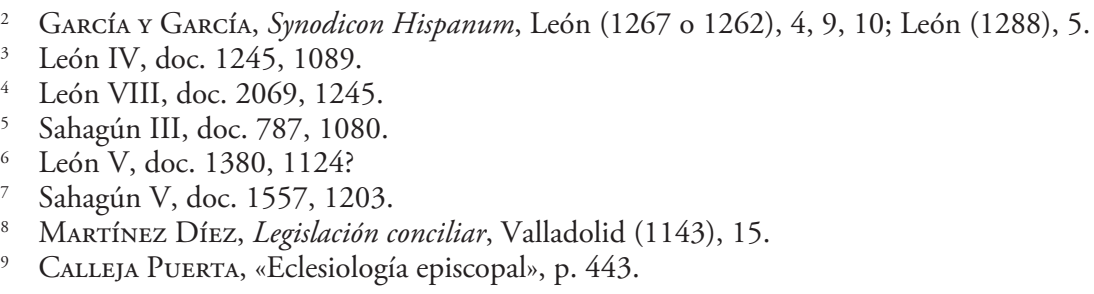


ENCUADRAMIENTO DEL CLERO LOCAL Y REORGANIZACIÓN ECLESIÁSTICA EN LA DIÓCESIS DE LEÓN (SIGLOS XI-XIII)

MARIEL PÉREZ

diversas referencias a visitas dentro de la diócesis de León. En 1219, la sentencia arbitral dictada por los jueces comisionados por Inocencio III en el pleito entre el obispo de León y el abad de Sahagún sobre la jurisdicción en las iglesias del burgo y coto del monasterio establecía que las visitas y procuraciones eran competencia del obispo secundum consuetudinem ipsius Legionis episcopatus ${ }^{80}$. Unos años después, el cabildo de León arrendaba al canónigo Martín Fernández las iglesias de San Antolín, Santa Marina, Santa Eugenia, Gigosos y Falvalles, especificando la obligación de recibir anualmente a los visitadores ${ }^{81}$. Similares condiciones se establecen para los clérigos García Fernández y Pedro Domínguez, que en 1245 recibían vitaliciamente la iglesia de San Salvador de Villalpando, comprometiéndose a recibir a los visitadores y entregarles las procuraciones ${ }^{82}$.

Por su parte, los sínodos tuvieron una importante función tanto en la formación del clero local como en la imposición de las normas de comportamiento clerical dictadas por la jerarquía eclesiástica, en tanto que constituían una instancia de transmisión de la legislación de la Iglesia hacia las diócesis particulares ${ }^{83}$. En el ámbito ibérico, el concilio de Valladolid de 1228 estipulaba la obligación de celebrar dos sínodos anuales ${ }^{84}$. Sin embargo, Francisco Cantelar Rodríguez advierte que esta periodicidad no habría sido habitual en ninguna diócesis ${ }^{85}$. Para la diócesis de León, si bien las primeras constituciones diocesanas datan de la década de 1260 , contamos con referencias a la celebración de sínodos desde mediados del siglo $\mathrm{XII}^{86}$. La frecuencia de estas reuniones y el grado de participación del clero local en las mismas resulta, lamentablemente, imposible de precisar.

\section{LOS INGRESOS ECLESIÁSTICOS Y LA TERCIA EPISCOPAL}

Otro aspecto a considerar para comprender el encuadramiento del clero local dentro de las estructuras eclesiásticas en formación es la evolución de los ingresos que recibían las iglesias locales y sus clérigos, así como la participación de la sede diocesana en los mismos.

Una parte de los ingresos de las iglesias locales derivaban de los derechos sobre tierras y villas que formaban parte de su dotación original o que adquirieron a través de donaciones, permutas y compraventas. Otra fuente de ingresos se vinculaba a las propiedades que detentaban los clérigos a título personal. Para la Alta Edad Media, se registran

80 León VI, doc. 1880, 1219.

81 «Teneor etiam uisitatores a uobis datos recipere annuatim», León VIII, doc. 2010, 1235.

82 «Alios socios nostros quociens inde transsire contigerit bene recipiat, nec tamen ad ipsorum procurationem uolumus teneatur», León VIII, doc. 2067, 1245.

83 Vid. Ríos Rodríguez, María Luz y Díez Herrera, Carmen. "La vie du clergé rural dans le nord de l'Espagne médiévale d'après les actes synodaux». En Bonnassie (ed.), Le clergé rural, pp. 171-172.

84 Martínez Díez, Legislación conciliar, Valladolid (1228), I, 2-5.

85 Cantelar Rodríguez, Francisco. «El 'Synodicon Hispanum', espejo de la España Medieval». Anuario de Historia de la Iglesia, 2008, vol. 17, p. 338.

86 León V, doc. 1510, 1159; doc. 1629, 1182; León VI, doc. 1691, 1190; doc. 1849 [1215]; doc. $1880,1219$. 
ENCUADRAMIENTO DEL CLERO LOCAL Y REORGANIZACIÓN ECLESIÁSTICA

EN LA DIÓCESIS DE LEÓN (SIGLOS XI-XIII)

MARIEL PÉREZ

presbíteros en posesión de amplios conjuntos patrimoniales, lo que situaba a estos clérigos -en ocasiones propietarios de las iglesias- dentro del ámbito de las élites rurales ${ }^{87}$. De hecho, puede plantearse que, en un contexto caracterizado por el escaso grado de institucionalización de las exacciones eclesiásticas, la base de reproducción material de estos presbíteros rurales derivaba en gran medida de su propio patrimonio.

No obstante, con el tiempo se fueron definiendo y afirmando una serie de rentas de carácter eclesiástico, entre las que se destacan los diezmos y primicias, ofrendas a pie de altar y donaciones. De acuerdo con la normativa de la Primera Partida, las primicias consistían en la primera parte de los frutos de la tierra (trigo, centeno, cebada, vino, aceite) y debían ser entregadas por los laicos a los clérigos de las iglesias parroquiales en las que recibían los sacramentos ${ }^{88}$. Hay algunas referencias a su pago en las iglesias de la diócesis leonesa. Aparece, por ejemplo, en el acuerdo suscrito por el monasterio de Sahagún y doña María Gómez, donde se establecía que toda iglesia dentro del señorío de Villavicencio debía corresponder al monasterio cum suis decimis et suis primitiis et cum toto suo offerto et cum toto suo mortuorum ${ }^{89}$. A su vez, en 1192 Pedro Peláez y su mujer, Teresa Núnez entregaban las iglesias de San Martín de Coria y San Bábile de Quintanilla al monasterio de San Salvador, junto con sus diezmos, primicias y ofrendas ${ }^{90}$.

Pero la base del ingreso eclesiástico -y sostén estructural del señorío episcopalsería el diezmo ${ }^{91}$. Si bien hay referencias tempranas al pago de diezmos, suele considerarse que su generalización con carácter obligatorio data de mediados del siglo XI, con el inicio del proceso de formación de la parroquia ${ }^{92}$. En cualquier caso, el cobro del diezmo parece ser una costumbre extendida en la segunda mitad del siglo XI, al menos en las iglesias que, pertenecientes a monasterios o familias aristocráticas, se hallaban respaldadas por estructuras capaces de garantizar y gestionar su pago. Así

87 Sahagún I, doc. 168, 959; León IV, doc. 911, 1033; doc. 918, 1033; doc. 991, 1040; doc. 1074, 1050; doc. 1099, 1055; doc. 1245, 1089; Sahagún II, doc. 630, 1063; doc. 633, 1063; doc. 665, 1067; Sahagún III, doc. 787, 1080; doc. 903, 1093; doc. 1027, 1098.

88 Primera Partida, tít. XIX, leyes II, III y VII.

89 Sahagún IV, doc. 1259, 1136.

90 «Nunc, penitenciam agimus et eam liberam ad partem Sancti Saluatoris dimittimus; ita ut ab hodie et deinceps, decimas et primicias et oblationes de uassallis uestris prior et fratres Sancti Saluatoris de Uillacete in eternum habeant. Similiter de ecclesia Sancti Babile de Quintenella concedimus», Sahagún IV, doc. 1465, 1192.

91 Sobre el cobro, beneficiarios y valor económico del diezmo en el norte hispánico, vid. MarTín Rodríguez, José Luis. «Diezmos eclesiásticos. Notas sobre la economía de la sede zamorana (s. XIIXIII)». En ÍDEM. Amor, cuestión de señorio y otros estudios zamoranos. Zamora: Universidad Nacional de Educación a Distancia, 1993, pp. 53-62, y Díaz de Durana, José Ramón y Guinot, Enric. «La dîme dans l'Espagne médiévale». En VIADER, Roland (ed.). La dîme dans l'Europe médiévale et moderne. Actes des XXX's Journées Internationales d'Histoire de l'Abbaye de Flaran, 3 et 4 octobre 2008. Toulouse: Presses Universitaires du Mirail, 2010, pp. 63-88.

92 Martínez Sopena, La Tierra de Campos, p. 296, n. 147; García de Cortázar, José Ángel. La sociedad rural en la España Medieval. Madrid: Siglo XXI, 1988, p. 90; CAlleja Puerta, La formación de la red parroquial, p. 99; DAvies, «Local priests», pp. 134-135. López Alsina matiza esta interpretación, considerando que la obligatoriedad del pago del diezmo era anterior a dicho período, López Alsina, «El encuadramiento eclesiástico», p. 454. 
pues, en 1071 doña Justa y doña Mumadonna hacían referencia a los diezmos del pan y el vino que percibían en sus iglesias, cuya tercia donaban al obispo ${ }^{93}$. Por su parte, en el pleito que en 1091 enfrentó al obispo de León con el abad de Sahagún por las tercias de las iglesias que tenía el monasterio (muchas de las cuales se correspondían con centros religiosos que habían pertenecido con anterioridad a la aristocracia laica), se afirmaba que este retenía las tercias cum more antiquo, lo que sugiere que el cobro del diezmo era visto como una práctica habitual ${ }^{94}$. Sin embargo, la institucionalización del cobro del diezmo se consolidaría de forma definitiva a mediados del siglo XIII, lo que debe vincularse no solo a los preceptos sancionados en el IV Concilio de Letrán (c. 53-55), que afirma la obligación de todos los cristianos de pagar el diezmo a la Iglesia, sino también, en el ámbito ibérico, al afianzamiento y generalización de la estructura parroquial y a la introducción de las «tercias reales», que habría hecho necesario para la monarquía garantizar a la Iglesia el cobro regular del diezmo. Esta voluntad se pone de manifiesto en la Primera Partida, que dedica su título XX a establecer un marco normativo detallado sobre su percepción. La consolidación del sistema diezmal instituiría de forma definitiva la parroquia en su forma clásica, convertida en unidad de recaudación del diezmo en una feligresía definida por un marco territorial concreto.

Contamos con diversas referencias al pago del diezmo en la diócesis de León, donde consistía usualmente en productos como pan, vino, cebada, lino, legumbres y productos hortícolas ${ }^{95}$. Esto cobra interés a la luz de la variabilidad que presentaba la percepción decimal en las diferentes regiones de la Península ${ }^{96}$. El valor económico del diezmo no ha sido precisado para este período, dado que las fuentes disponibles no ofrecen datos que permitan un estudio sistemático al respecto. No obstante, el monto recaudado variaba en relación con el número de feligreses de cada parroquia y el nivel de producción agraria, entre otros factores.

En teoría, el diezmo recaudado en cada iglesia se dividía en tres partes: una para los clérigos que la servían, una para la fábrica (construcción y reparación de la iglesia, gastos del culto, vasos y vestimentas litúrgicas) y una para el obispo y los prebendados de la catedral. A su vez, desde mediados del siglo XIII -y con autorización pontificia- la monarquía comenzaría a participar de los ingresos decimales a través de las tercias reales,

93 León IV, doc. 1175, 1071; doc. 1176, 1071.

94 León IV, doc. 1260, 1091.

95 «Fecerunt testamentum ut darent de omnis decimationis panis ac uini tertia portio ad eandem sedem», León IV, doc. 1176, 1071; «demus de quantitate decimatione collegerimus, tam de ciuaria quam de uino, IIIa portione per hemina et per cantara ad ipsa sede per unicuique anno», León IV, doc. 1180, 1071; «ut demus uobis et ad sedem Sancte Marie sedis Legionensis per singulis annis tertia de illo decimo de ciuaria et uino per emina et cantara, sicut canones docet pagato, et uno kantaro ille monaco", León IV, doc. 1206, 1077; el conde Nuño y su esposa donan a la sede de León «omnium fructuum tercias, panis, et uini, et lini, et uniuersi generis leguminum, et hortorum fructuum» de las iglesias de Cuenca de Campos, León V, doc. 1555, 1170; Rodrigo Roderici y sus hermanos donan a la iglesia de León «terciarius annuatim ex parte Sancte Marie recipiatur in Sancta Eufemia ad colligendam terciam de pane, et de uino, et de legumine», León V, doc. 1565, 1171.

96 Díaz de Durana y Guinot, «La dîme dans l’Espagne médiévale», pp. 70-71. 
ENCUADRAMIENTO DEL CLERO LOCAL Y REORGANIZACIÓN ECLESIÁSTICA

EN LA DIÓCESIS DE LEÓN (SIGLOS XI-XIII)

MARIEL PÉREZ

que consistían en las dos terceras partes del tercio reservado a la fábrica ${ }^{97}$. Sin embargo, como seńala Fernández Flórez, la realidad que refleja el Becerro de Presentaciones para la segunda mitad del siglo XIII no se ajusta a estos sistemas, ya que, si bien se advierte una división en tercias, se ponen en juego diversos esquemas de reparto en los que aparecen otros actores como el rey, los patronos laicos, prestameros, monasterios o concejos ${ }^{98}$.

La tercia del diezmo destinada a los clérigos era el componente básico de la mayoría de los beneficios. Por lo tanto, como señalaba José Luis Martín, los ingresos de los beneficiados resultaban muy desiguales en las distintas parroquias, dependiendo del número de feligreses de cada una y de la extensión y fertilidad de sus propiedades ${ }^{99}$. Para el siglo XIII resulta visible la preocupación de las jerarquías eclesiásticas por que las iglesias pudieran afrontar el costo material que implicaba la concesión de un beneficio. El sínodo diocesano de León de 1288 establecía que los clérigos presentados para su nombramiento tuvieran las mismas provisiones que sus predecesores para que pudieran vivir dignamente; fijaba además la renta mínima para un beneficio en 40 cargas de pan anuales más el pie de $a_{1} \operatorname{tar}^{100}$. A su vez, el sínodo de 1306 establecía que en las iglesias patrimoniales no sea presentado ningún clérigo a menos que la iglesia dispusiera de una renta mínima para proveer el beneficio ${ }^{101}$. De hecho, se ha señalado la penuria material de muchos de estos clérigos y se ha sugerido que algunos de ellos podían vivir en una situación muy similar al resto de los campesinos de la comunidad, desarrollando actividades rurales ${ }^{102}$.

La entrega de la tercia decimal a la sede diocesana es uno de los aspectos más destacados de la subordinación de las iglesias locales y sus clérigos a la jurisdicción episcopal, así como de la formación del señorío episcopal. En León, la tercia aparece de forma genérica en 1065, cuando doña Toda y sus hijos ponían bajo jurisdicción episcopal todas sus iglesias y donaban al obispo de monasterios tertias uotos ${ }^{103}$; a su vez, en 1066, Diego Pétriz concedía a la sede las tertias uel usuras de sus iglesias ${ }^{104}$. Ya en 1071, dońa Justa y doña Mumadonna donaban al obispo la tercia, que aparece por primera vez como tercia de los diezmos del pan y el vino ${ }^{105}$. Por los mismos años, algunas iglesias vinculadas a comunidades rurales comenzaban también a quedar bajo jurisdicción episcopal y se comprometían a entregar al obispo la tercia de los diezmos junto a otras rentas. En 1070, el

97 En 1247 Inocencio IV concedió a Fernando III parte de la tercia correspondiente a la fábrica de la iglesia por tres años, aunque otros monarcas continuaron percibiéndola a pesar de la oposición del Papado, vid. Linehan, Peter. La Iglesia española y el papado en el siglo XIII. Salamanca: Universidad Pontificia de Salamanca, 1975, pp. 99 y ss.

98 Fernández Flórez, «El Becerro de Presentaciones», pp. 309-315. Para la diócesis de Zamora, por ejemplo, José Luis Martín indica que en algunos casos los patronos recibían una parte más importante de los diezmos recaudados y se encargaban de pagar los gastos del culto y remunerar a los clérigos, Martín Rodríguez, «Diezmos eclesiásticos», p. 61.

99 Martín Martín, «Beneficios y oficios», p. 729.

100 García y García, Synodicon Hispanum, León (1288), 6, 12.

101 García y García, Synodicon Hispanum, León (1306), 2.

102 Martín Martín, «El clero rural», p. 56.

103 León IV, doc. 1136, 1065.

104 León IV, doc. 1142, 1066.

105 León IV, doc. 1175, 1071; doc. 1176, 1071. 
obispo Gonzalo consagraba la iglesia de los Santos Cosme y Damián del Valle de Oncina en nombre del obispo Pelayo de León, a cuya diócesis pertenecía, y se establecía que la iglesia habría de pagar los mismos censos que las otras de la diócesis ${ }^{106}$. En 1077, los hombres de Villa Vega se comprometían a entregar a la sede el tercio del diezmo del pan y el vino en ocasión de la consagración de la iglesia local por parte del obispo Pelayo ${ }^{107}$. Los laicos no dejarían, sin embargo, de retener parte de los diezmos, a pesar de las reiteradas disposiciones de los concilios leoneses contra esta práctica ${ }^{108}$. De hecho, como muestra el Becerro de Presentaciones, en la segunda mitad del siglo XIII aristocracias, concejos e instituciones religiosas percibían las tercias de muchas iglesias en tanto patronos ${ }^{109}$.

Una serie de documentos referidos a la iglesia de Santa María del Vico Francorum, en la ciudad de León, revela la insistencia de los obispos en asegurarse el cobro de la tercia episcopal, que en este caso -teniendo en cuenta que se trataba de una iglesia del ámbito urbano-debía resultar significativa. Así, sucesivos presbíteros se comprometían a entregar a la sede legionense la tercera parte de los diezmos, ofrendas y mandas de difuntos que percibiera la iglesia ${ }^{110}$. De igual manera, en 1145 el capellán de San Martín del Mercado, también en la ciudad de León, prometía entregar a la sede las tercias de los ingresos eclesiásticos que percibiera su iglesia, permaneciendo siempre obediente al obispo y sin retener ningún derecho correspondiente a la catedral ${ }^{111}$. No obstante, la entrega de la tercia podía ser objeto de negociación entre los obispos y los clérigos. Así, la tercia episcopal podía ser conmutada por una renta fija, de modo que el clérigo beneficiado retuviera el diezmo recaudado y entregara al obispo una renta que podía incluir montos en metálico. Por ejemplo, en 1138 el presbítero Constancio, capellán del burgo de Mansilla, se comprometía a entregar anualmente a la sede de León cuatro morabetinos, una libra de incienso y un carnero a cambio de la tercia de su iglesia, acuerdo cuya continuidad quedaría sujeta a la voluntad del obispo ${ }^{112}$.

En ocasiones se podía llegar a acuerdos más complejos. En 1232, el obispo Rodrigo de León lograba que los clérigos y laicos de Malillos reconocieran la propiedad de la sede leonesa sobre la iglesia de Santiago. Como parte del acuerdo, se establecía un reparto de la percepción decimal y otros ingresos eclesiásticos entre los clérigos locales y quien tuviera la iglesia en nombre de la sede de León. Mientras que este último elegiría anualmente tres dezmeros, los clérigos elegirían cinco, de los que recibirían los diezmos y beneficios en tanto sirviesen a la iglesia, cumplieran los pedidos del obispo, el arcediano y el arcipreste, y entregaran cada año dos maravedíes por San Martín al que tuviera la iglesia. A la vez, los clérigos recibirían veinte stopos de pan y podrían retener las ofrendas, mortuorias y oblaciones a pie de altar. No obstante, a medida que fallecieran los clérigos, sus derechos pasarían a quien tuviera la iglesia en nombre de la sede ${ }^{113}$.

106 León IV, doc. 1172, 1070.

107 León IV, doc. 1206, 1077.

108 Martínez DíEz, Legislación conciliar, León (1114), 3; Compostela (1119), 17; Palencia (1129), 17; Valladolid (1143), 10.

109 Fernández FlóreZ, «El Becerro de Presentaciones», pp. 355-521.

110 León V, doc. 1428, 1140; León V, doc. 1478, 1153; León V, doc. 1570, 1171.

111 León V, doc. 1447, 1145.

112 León V, doc. $1423,1138$.

113 León VIII, doc. 1992, 1232. 
ENCUADRAMIENTO DEL CLERO LOCAL Y REORGANIZACIÓN ECLESIÁSTICA

EN LA DIÓCESIS DE LEÓN (SIGLOS XI-XIII)

MARIEL PÉREZ

\section{Conclusiones}

Una de las facetas del profundo proceso de reorganización eclesiástica que impulsó la Reforma Gregoriana fue la sujeción de las iglesias locales al poder episcopal, integrada a una estructura parroquial, y el encuadramiento de sus clérigos -en el marco de una política unificadora proveniente del Papado- a un conjunto de normas que reglamentaban sus prácticas y comportamientos. En este contexto, entre los siglos XI y XIII el clero local experimentó profundas transformaciones en relación con la situación que lo caracterizó en la Alta Edad Media.

Debe destacarse, en primer lugar, la progresiva definición de los mecanismos de ingreso al clero y acceso a los beneficios y el afianzamiento de las prerrogativas del obispo en el nombramiento de los clérigos. La regulación de los mecanismos de provisión eclesial implicó también, en línea con las ideas gregorianas, combatir las prácticas simoníacas y la intervención de los laicos en la designación de los clérigos. A su vez, a través del desarrollo de una intensa actividad conciliar se apuntó a regular las costumbres del clero y su práctica litúrgica de acuerdo con las nuevas concepciones del orden eclesiástico. Por otra parte, el fortalecimiento de las estructuras eclesiásticas y el desarrollo del sistema parroquial permitieron la generalización y afirmación del cobro del diezmo. Esto produjo una profunda transformación en los mecanismos de reproducción material del clero local, que dejó de tener su base primaria en el patrimonio de los clérigos y sus iglesias para sustentarse progresivamente sobre la exacción institucionalizada del diezmo.

Ahora bien, el encuadramiento del clero local estuvo condicionado por las dinámicas sociales locales, que impusieron ciertos límites al control episcopal. Esto se manifestó de manera señalada en las prerrogativas que lograron mantener los patronos laicos y eclesiásticos sobre algunas iglesias en relación con el derecho a la presentación de los clérigos y la percepción de parte de los diezmos. Por otra parte, la prolongada insistencia de la legislación eclesiástica en una serie de cuestiones, como la simonía, el nombramiento laico, el celibato o la disciplina, pone en evidencia las dificultades que tuvieron los reformadores para concretar sus objetivos de renovación de la vida del clero.

En conjunto, puede plantearse que a lo largo del período estudiado se reforzaron una serie de rasgos objetivos y simbólicos que identificaban a los clérigos locales con un estamento eclesiástico definido con creciente nitidez y los subordinaban a una estructura vertical bajo la autoridad unificadora del Papado. Kathleen Cushing ha señalado, en este sentido, que entre los logros más notables de los reformadores estuvo lo que denomina una "reorientación de lealtades», es decir, el reconocimiento por parte del clero de que su identidad se ubicaba, ante todo, dentro de la esfera eclesiástica, una esfera marcada por el estatus religioso $-\mathrm{y}$, crecientemente, por el celibato-, que separaba a los oratores del resto de la sociedad ${ }^{114}$. No obstante, la vinculación que mantenían con los poderes locales y las comunidades de las que formaban parte nos permite pensar que, desde un punto de vista sociológico, estos clérigos se hallaban en una posición tensionada entre la

114 Cushing, Reform and papacy, p. 35. 
pertenencia al estamento religioso y su participación activa dentro de dinámicas sociales desarrolladas a escala local.

\section{REFERENCIAS BIBLIOGRÁFICAS}

Alfonso Antón, Isabel. «Iglesias rurales en el norte de Castilla: una dimensión religiosa de las luchas campesinas en la Edad Media». En Robledo, Ricardo (ed.). Sombras del progreso. Las huellas de la historia agraria. Barcelona: Crítica, 2010, pp. 27-65.

Álvarez Borge, Ignacio. Poder y relaciones sociales en Castilla en la Edad Media. Los territorios entre el Arlanzón y el Duero en los siglos X al XIV. Salamanca: Junta de Castilla y León, 1996.

Álvarez Palenzuela, Vicente Ángel. "Jurisdicción episcopal y monástica: su delimitación entre el Obispado de León y el Monasterio de Sahagún». En Escritos dedicados a José María Fernández Catón. Vol. 1. León: Centro de Estudios e Investigación San Isidoro, 2004, pp. 65-85.

Aubrun, Michel. La paroisse en France des origines au XV siècle. Paris: Picard, 1986.

Ayala Martínez, Carlos de. Sacerdocio y reino en la España altomedieval. Iglesia y poder político en el Occidente peninsular, siglos VII-XII. Madrid: Sílex, 2008.

Bonnassie, Pierre (ed.). Le clergé rural dans l'Europe médiévale et moderne. Actes des XIII' Journées Internationales d'Histoire de l'Abbaye de Flaran, 6-8 septembre 1991. Toulouse: Presses Universitaires du Mirail, 1995.

Calleja Puerta, Miguel. «Eclesiología episcopal y organización del espacio en las ciudades y villas del noroeste peninsular (1100-1250)». En Iglesia Duarte, José Ignacio de la (coord.). Monasterios, espacio y poder en la España cristiana medieval. XX Semana de Estudios Medievales. Nájera, 2009. Logroño: Instituto de Estudios Riojanos, 2010, pp. 429-490.

Calleja Puerta, Miguel. La formación de la red parroquial de la diócesis de Oviedo en la Edad Media. Oviedo: Real Instituto de Estudios Asturianos, 2000.

Calvo Gómez, José Antonio. «Rasgos de la reforma del clero en la Península Ibérica durante el siglo XI». Studia Historica. Historia Medieval, 2015, vol. 33, pp. 201-232.

Cantelar Rodríguez, Francisco. «El 'Synodicon Hispanum', espejo de la España Medieval». Anuario de Historia de la Iglesia, 2008, vol. 17, pp. 337-341.

Catalán Martínez, Elena. «El derecho de patronato y el régimen beneficial de la Iglesia española en la Edad Moderna». Hispania Sacra, 2004, vol. 56, n. ${ }^{\circ} 113$, pp. 135-167.

Catalán Martínez, Elena. «Parroquias y curas en el obispado de Calahorra y La Calzada (siglos XI-XVI)». Obradoiro de Historia Moderna, 2013, vol. 22, pp. 35-62.

Cimino, Carla. «Las iglesias locales, los señores feudales y la comunidad. Dinámicas de consolidación del episcopado castellano-leonés, 1150-1250». Trabajos y comunicaciones, 2013, vol. 39. En http://www.trabajosycomunicaciones.fahce.unlp.edu.ar/article/view/TyC2013n39a11.

Cowdrey, Herbert Edward John. Pope Gregory VII, 1073-1085. Oxford: Clarendon Press, 1998.

Cushing, Kathleen G. Reform and papacy in the eleventh century: spirituality and social change. Manchester: Manchester University Press, 2005.

Davies, Wendy. «Local priests in northern Iberia». En Patzold, Steffen y Van Rhijn, Carine (eds.). Men in the Middle. Local Priests in Early Medieval Europe. Berlin: De Gruyter, 2016, pp. 124-144.

Davies, Wendy. Acts of Giving: Individual, Community and Church in Tenth-Century Christian Spain. Oxford: Oxford University Press, 2007.

Deswarte, Thomas. Une Chrétienté romaine sans pape: l'Espagne et Rome (586-1085). Paris: Garnier, 2010. 
ENCUADRAMIENTO DEL CLERO LOCAL Y REORGANIZACIÓN ECLESIÁSTICA

EN LA DIÓCESIS DE LEÓN (SIGLOS XI-XIII)

MARIEL PÉREZ

Díaz de Durana, José Ramón. "Patronatos, patronos, clérigos y parroquianos: los derechos de patronazgo sobre monasterios e iglesias como fuente de renta e instrumento de control y dominación de los parientes mayores guipuzcoanos (siglos XIV a XVI)». Hispania Sacra, 1998, vol. 50 , n. ${ }^{\circ} 102$, pp. 467-508.

Díaz de Durana, José Ramón y Guinot, Enric. «La dîme dans l'Espagne médiévale». En ViADER, Roland (ed.). La dîme dans l'Europe médiévale et moderne. Actes des XXXes Journées Internationales d'Histoire de l'Abbaye de Flaran, 3 et 4 octobre 2008. Toulouse: Presses Universitaires du Mirail, 2010, pp. 63-88.

Domínguez SÁnchez, Santiago. Documentos pontificios referentes a la diócesis de León (siglos XIXIII). León: Universidad de León, 2003.

Estepa Díez, Carlos. «Poder y propiedad feudales en el período astur: las mandaciones de los Flaínez en la montaña leonesa». En Miscel.lania en homenatge al P. Augusto Altisent. Tarragona: Diputació de Tarragona, 1991, pp. 285-328.

FACI LACASTA, Francisco Javier. «Reforma gregoriana, reforma eclesiástica». En SER QuiJANo, Gregorio del y MarTín Viso, Ińaki (eds.). Espacios de poder y formas sociales en la Edad Media: estudios dedicados a Ángel Barrios. Salamanca: Universidad de Salamanca, 2007, pp. 77-90.

Fernández Catón, José María. Colección documental del Archivo de la Catedral de León (7751230), vol. V (1109-1187). León: Centro de Estudios e Investigación San Isidoro, 1990.

Fernández Catón, José María. Colección documental del Archivo de la Catedral de León (7751230), vol. VI (1188-1230). León: Centro de Estudios e Investigación San Isidoro, 1991.

Fernández Flórez, José Antonio. «El Becerro de Presentaciones, códice 13 del Archivo de la Catedral de León. Un parroquial leonés de los siglos XIII-XV». En León y su historia. Miscelánea histórica, $V$. León: Centro de Estudios e Investigación San Isidoro, 1984, pp. 355-521.

Fernández Flórez, José Antonio. Colección diplomática del monasterio de Sahagún, vol. IV (11101199). León: Centro de Estudios e Investigación San Isidoro, 1991.

Fernández Flórez, José Antonio. Colección diplomática del monasterio de Sahagún, vol. V(12001300). León: Centro de Estudios e Investigación San Isidoro, 1994.

FÉrotin, Marius. Le Liber Ordinum en usage dans l'Église wisigothique et mozarabe d'Espagne du cinquième au onzième siècle. Paris: Librairie de Firmin Didot, 1904.

Fletcher, Richard. The Episcopate in the Kingdom of Leon in the Twelfth Century. Oxford: Oxford University Press, 1978.

García de Cortázar, José Ángel. La sociedad rural en la España Medieval. Madrid: Siglo XXI, 1988.

García Gallo, Alfonso. «El concilio de Coyanza. Contribución al estudio del Derecho Canónico español en la Alta Edad Media». Anuario de Historia del Derecho Español, 1951, vol. XIXXX, pp. 275-633.

García García, Élida. «Monasterios benedictinos y aristocracia laica en Asturias (siglos XI y XII)». En Semana de Historia del Monacato Cántabro-Astur-Leonés. Oviedo: Monasterio de San Pelayo, 1982, pp. 195-233.

García y García, Antonio. "Concilios y sínodos en el ordenamiento jurídico del reino de León». En Fernández Catón, José María (ed.). El Reino de León en la Alta Edad Media. 1. Cortes, concilios y fueros. León: Centro de Estudios e Investigación San Isidoro, 1988.

García y García, Antonio. "Legislación de los concilios y sínodos del reino leonés». En FernÁndez Catón, José María (ed.). El Reino de León en la Alta Edad Media. 2. Ordenamiento jurídico del reino. León: Centro de Estudios e Investigación San Isidoro, 1992, pp. 9-113.

García y García, Antonio. Synodicon Hispanum. Vol. 3: Astorga, León y Oviedo. Madrid: Biblioteca de Autores Cristianos, 1981. 
Gaudemet, Jean. «La paroisse au Moyen Âge». Revue d'Histoire de l'Église de France, 1973, vol. 59, n. ${ }^{\circ} 162$, pp. 5-21.

Godoy, Analía. «Los presbíteros locales y sus estrategias de ascenso social en las comunidades campesinas leonesas del siglo X». Calamus, 2017, vol. 1, pp. 105-136.

Herrero de la Fuente, Marta. Colección diplomática del monasterio de Sahagún, vol. II (10001073). León: Centro de Estudios e Investigación San Isidoro, 1988.

Herrero de la Fuente, Marta. Colección diplomática del monasterio de Sahagún, vol. III (10731109). León: Centro de Estudios e Investigación San Isidoro, 1988.

Linehan, Peter. La Iglesia española y el papado en el siglo XIII. Salamanca: Universidad Pontificia de Salamanca, 1975.

López Alsina, Fernando. «El encuadramiento eclesiástico como espacio de poder: de la parroquia al obispado». En Iglesia Duarte, José Ignacio de la (coord.). Los espacios de poder en la España medieval. XII Semana de Estudios Medievales. Nájera, 30 de julio al 3 de agosto de 2001. Logrońo: Instituto de Estudios Riojanos, 2002, pp. 425-457.

López Alsina, Fernando. "La reforma eclesiástica: la generalización de un modelo parroquial renovado». En La reforma gregoriana y su proyección en la cristiandad occidental: siglos XI-XII. XXXII Semana de Estudios Medievales. Estella, 18 a 22 de julio de 2005. Pamplona: Gobierno de Navarra-Institución Príncipe de Viana, 2006, pp. 421-450.

López Alsina, Fernando. «Parroquias y diócesis: el obispado de Santiago de Compostela». En García de Cortázar, José Ángel (ed.). Del Cantábrico al Duero. Trece estudios sobre organización social del espacio en los siglos VIII a XIII. Santander: Universidad de Cantabria-Parlamento de Cantabria, 1999, pp. 263-312.

Loring García, María Isabel. «Nobleza e iglesias propias en la Cantabria altomedieval». Studia Historica. Historia Medieval, 1987, vol. V, pp. 89-120.

Mansilla Reoyo, Demetrio. La documentación pontificia hasta Inocencio III (956-1216). Roma: Instituto Español de Estudios Eclesiásticos, 1955.

Mariño Veiras, Dolores. «Renovación cultural y monástica en León y Castilla al servicio del poder público-religioso: el protagonismo de presbíteros y diáconos durante el segundo tercio del siglo X». En Torres Prieto, Juana María (ed.). Historica et Philologica in honorem José María Robles. Cantabria: Universidad de Cantabria, 2002, pp. 153-168.

Martín Martín, José Luis. "Beneficios y oficios del clero rural castellano (siglos XIII-XV)». Anuario de Estudios Medievales, 2005, vol. 35, n. ${ }^{\circ}$ 2, pp. 693-736.

Martín Martín, José Luis. «El clero rural en la Corona de Castilla». En Martínez San Pedro, María de los Desamparados y Segura del Pino, Dolores (coords.). La iglesia en el mundo medieval y moderno. Almería: Instituto de Estudios Almerienses, 2004, pp. 55-82.

Martín Rodríguez, José Luis. «Diezmos eclesiásticos. Notas sobre la economía de la sede zamorana (s. XII-XIII)». En ÍDEM. Amor, cuestión de señorío y otros estudios zamoranos. Zamora: Universidad Nacional de Educación a Distancia, 1993, pp. 53-62.

Martín Viso, Iñaki. Poblamiento y estructuras sociales en el norte de la Peninsula Ibérica (siglos VIXIII). Salamanca: Universidad de Salamanca, 2000.

Martínez Díez, Gonzalo. Legislación conciliar del Reino Astur (718-910) y del Reino de León (9101230). León: Centro de Estudios e Investigación San Isidoro, 2009.

Martínez Sopena, Pascual. «Aristocracia, monacato y reformas en los siglos XI y XII». En El monacato en los reinos de León y Castilla (siglos VII-XIII). X Congreso de Estudios Medievales 2005. Ávila: Fundación Sánchez-Albornoz, 2007, pp. 67-100.

Martínez Sopena, Pascual. «Fundaciones monásticas y nobleza en los reinos de Castilla y León en la época románica». En García de CorTÁzAR, José Ángel (coord.). Monasterios románicos y producción artística. Aguilar de Campoo: Fundación de Santa María la Real, 2003, pp. 35-62. 
ENCUADRAMIENTO DEL CLERO LOCAL Y REORGANIZACIÓN ECLESIÁSTICA

EN LA DIÓCESIS DE LEÓN (SIGLOS XI-XIII)

MARIEL PÉREZ

Martínez Sopena, Pascual. «Monasterios particulares, nobleza y reforma eclesiástica en León entre los siglos XI y XII». En Estudios de historia medieval. Homenaje a Luis Suárez Fernández. Valladolid: Universidad de Valladolid, 1991, pp. 323-331.

Martínez Sopena, Pascual. La Tierra de Campos occidental. Poblamiento, poder y comunidad del siglo X al XIII. Valladolid: Institución Cultural Simancas, 1985.

MíngueZ FernándeZ, José María. Colección diplomática del monasterio de Sahagún (siglos IX y X). León: Centro de Estudios e Investigación San Isidoro, 1976.

Patzold, Steffen y Van Rhijn, Carine (eds.). Men in the Middle. Local Priests in Early Medieval Europe. Berlin: De Gruyter, 2016.

Peña Bocos, Esther. La atribución social del espacio en la Castilla altomedieval. Una nueva aproximación al feudalismo peninsular. Santander: Universidad de Cantabria, 1995.

Peñalva Git, Jesús. «Las iglesias patrimoniales en la Castilla medieval. La iglesia parroquial de San Nicolás de Burgos: institución, ordenanzas y regla de 1408». Anuario de Estudios Medievales, 2008, vol. 38, n. ${ }^{\circ} 1$, pp. 301-366.

PÉREZ, Mariel. «El control de lo sagrado como instrumento de poder: los monasterios particulares de la aristocracia altomedieval leonesa». Anuario de Estudios Medievales, 2012, vol. 42, n. ${ }^{\circ} 2$, pp. 799-822.

PÉREZ, Mariel. «Proprietary Churches, Episcopal Authority and Social Relationships in the Diocese of León (1 $11^{\text {th }}-12^{\text {th }}$ Centuries)». Journal of Medieval Iberian Studies, 2018, vol. 10, n.o 2, pp. 195-212. En https://www.tandfonline.com/doi/full/10.1080/17546559.2017.1315645.

Reglero de la Fuente, Carlos. «La primera reforma cluniacense de Sahagún, el concilio de Burgos y la crisis de 1080: revisión cronológica y desarrollo». En Fernández Catón, José María (ed.). Monarquía y sociedad en el reino de León. De Alfonso III a Alfonso VII, vol. 2. León: Centro de Estudios e Investigación San Isidoro, 2007, pp. 689-732.

Reglero de la Fuente, Carlos. «La Reforma Gregoriana y la introducción del rito romano». En Escudero, José Antonio (dir.). La Iglesia en la Historia de España. Madrid: Marcial Pons, 2014, pp. 317-326.

Reglero de la Fuente, Carlos. «Los obispos y sus sedes en los reinos hispánicos occidentales». En La reforma gregoriana y su proyección en la cristiandad occidental: siglos XI-XII. XXXII Semana de Estudios Medievales. Estella, 18 a 22 de julio de 2005. Pamplona: Gobierno de NavarraInstitución Príncipe de Viana, 2006, pp. 195-288.

Reilly, Bernard F. The Kingdom of Leon-Castilla under King Alfonso VI, 1065-1109. Princeton: Princeton University Press, 1988.

Ríos Rodríguez, María Luz y Díez Herrera, Carmen. «La vie du clergé rural dans le nord de l'Espagne médiévale d'après les actes synodaux». En Bonnassie, Pierre (ed.). Le clergé rural dans l'Europe médiévale et moderne. Actes des XIII' Journées Internationales d'Histoire de l'Abbaye de Flaran, 6-8 septembre 1991. Toulouse: Presses Universitaires du Mirail, 1995, pp. 167-186.

Rivera Recio, Juan Francisco; Faci Lacasta, Francisco Javier y Oliver, Antonio. «La presencia de la Santa Sede en España». En García-Villoslada, Ricardo (dir.). Historia de la Iglesia en España. II. 1. La Iglesia en la España de los siglos VII al XIV. Madrid: Biblioteca de Autores Cristianos, 1982, pp. 259-297.

Rubio Sadia, Juan Pablo. «La introducción del canto gregoriano en Aragón: etapas y vicisitudes de un proceso de asimilación (siglos IX-XII)». En Prensa, Luis y Calahorra, Pedro (coords.). Jornadas de Canto Gregoriano: XV. El libro litúrgico: del scriptorium a la imprenta. XVI. La implantación en Aragón, en el siglo XII, del rito romano y del canto gregoriano. Zaragoza: Institución Fernando el Católico, 2012, pp. 171-201. 
Ruiz Asencio, José Manuel. Colección documental del Archivo de la Catedral de León (775-1230), vol. III (986-1031). León: Centro de Estudios e Investigación San Isidoro, 1990.

Ruiz Asencio, José Manuel. Colección documental del Archivo de la Catedral de León (775-1230), vol. IV (1032-1109). León: Centro de Estudios e Investigación San Isidoro, 1990.

Ruiz Asencio, José Manuel. Colección documental del Archivo de la Catedral de León (775-1230), vol. VIII (1230-1269). León: Centro de Estudios e Investigación San Isidoro, 1993.

Ruiz De LA PeÑa, José Ignacio. «La parroquia, célula de encuadramiento de la sociedad rural asturiana (siglos XI-XIII)». En Sesma Muñoz, José Ángel y Laliena Corbera, Carlos (coords.). La pervivencia del concepto: nuevas reflexiones sobre la ordenación social del espacio en la Edad Media. Zaragoza: Gobierno de Aragón y Grupo CEMA, 2008, pp. 197-218.

Ruiz de la Peña, José Ignacio. «Parroquias, concejos parroquiales y solidaridades vecinales en la Asturias medieval». Asturiensia Medievalia, 1993-1994, vol. 7, pp. 105-122.

Soto Rábanos, José María. "Introducción del rito romano en los reinos de España. Argumentos del papa Gregorio VII». Studi Gregoriani, 1991, vol. 14, pp. 161-174.

Soto RÁbanos, José María. «Pedagogía medieval hispana: transmisión de saberes en el bajo clero». Revista Española de Filosofía Medieval, 1995, vol. 2, pp. 43-58. 